\title{
Protective Effects of PACAP in Peripheral Organs
}

\author{
Denes Toth ${ }^{1}$, Edina Szabo ${ }^{2}$, Andrea Tamas ${ }^{2}$, Tamas Juhasz ${ }^{3,4}$, Gabriella Horvath ${ }^{2}$, \\ Eszter Fabian ${ }^{2}$, Balazs Opper ${ }^{2}$, Dora Szabo ${ }^{5}$, Grazia Maugeri ${ }^{4}$, Agata G. D'Amico ${ }^{6}$, \\ Velia D'Agata ${ }^{4}$, Viktoria Vicena ${ }^{2}$ and Dora Reglodi ${ }^{2 *}$

\begin{abstract}
${ }^{1}$ Department of Forensic Medicine, MTA-PTE PACAP Research Team, University of Pécs Medical School, Pécs, Hungary, ${ }^{2}$ Department of Anatomy, MTA-PTE PACAP Research Team, University of Pécs Medical School, Pécs, Hungary, ${ }^{3}$ Department of Anatomy, Histology and Embryology, Faculty of Medicine, University of Debrecen, Debrecen, Hungary, ${ }^{4}$ Department of Biomedical and Biotechnological Sciences, Section of Human Anatomy and Histology, University of Catania, Catania, Italy, ${ }^{5}$ Heart Institute, Medical School, University of Pécs, Pécs, Hungary, ${ }^{6}$ Department of Drug Sciences, University
\end{abstract} \\ of Catania, Catania, Italy
}

\section{OPEN ACCESS}

Edited by:

Leo T. O. Lee,

University of Macau, China

Reviewed by:

Elena Gonzalez-Rey, Instituto de Parasitología y Biomedicina López-Neyra (IPBLN), Spain Hirokazu Ohtaki,

Showa University, Japan

*Correspondence: Dora Reglod dora.reglodi@aok.pte.hu

Specialty section: This article was submitted to Neuroendocrine Science, a section of the journal Frontiers in Endocrinology

Received: 12 February 2020 Accepted: 12 May 2020 Published: 14 July 2020

Citation:

Toth D, Szabo E, Tamas A, Juhasz T, Horvath G, Fabian E, Opper B, Szabo D, Maugeri G, D'Amico AG, $D$ 'Agata $V$, Vicena $V$ and Reglodi $D$ (2020) Protective Effects of PACAP in Peripheral Organs.

Front. Endocrinol. 11:377. doi: 10.3389/fendo.2020.00377
Pituitary adenylate cyclase activating polypeptide (PACAP) is a neuropeptide widely distributed in the nervous system, where it exerts strong neuroprotective effects. PACAP is also expressed in peripheral organs but its peripheral protective effects have not been summarized so far. Therefore, the aim of the present paper is to review the existing literature regarding the cytoprotective effects of PACAP in non-neuronal cell types, peripheral tissues, and organs. Among others, PACAP has widespread expression in the digestive system, where it shows protective effects in various intestinal pathologies, such as duodenal ulcer, small bowel ischemia, and intestinal inflammation. PACAP is present in both the exocrine and endocrine pancreas as well as liver where it reduces inflammation and steatosis by interfering with hepatic pathology related to obesity. It is found in several exocrine glands and also in urinary organs, where, with its protective effects being mainly published regarding renal pathologies, PACAP is protective in numerous conditions. PACAP displays anti-inflammatory effects in upper and lower airways of the respiratory system. In the skin, it is involved in the development of inflammatory pathology such as psoriasis and also has anti-allergic effects in a model of contact dermatitis. In the non-neuronal part of the visual system, PACAP showed protective effects in pathological conditions of the cornea and retinal pigment epithelial cells. The positive role of PACAP has been demonstrated on the formation and healing processes of cartilage and bone where it also prevents osteoarthritis and rheumatoid arthritis development. The protective role of PACAP was also demonstrated in the cardiovascular system in different pathological processes including hyperglycaemia-induced endothelial dysfunction and age-related vascular changes. In the heart, PACAP protects against ischemia, oxidative stress, and cardiomyopathies. PACAP is also involved in the protection against the development of pre-senile systemic amyloidosis, which is presented in various peripheral organs in PACAP-deficient mice. The studies summarized here provide strong evidence for the cytoprotective effects of the peptide. The survival-promoting effects of PACAP depend on a number of factors which are also shortly discussed in the present review. 


\section{INTRODUCTION}

Pituitary adenylate cyclase activating polypeptide (PACAP) was discovered more than 30 years ago by Arimura et al. (1). The discovery was based on the ability of the hypothalamus-derived peptide to increase cAMP levels in cultured pituitary cells. Several studies following its isolation showed that PACAP exerts several distinct effects in the hypothalamo-hypophyseal system and other central regulatory pathways (2-7). PACAP belongs to the glucagon/secretin/vasoactive intestinal peptide family of peptides and it exists in two forms, with 38 and 27 amino acids. PACAP acts on $G$ protein coupled receptors. The specific PAC1 receptor only binds PACAP, while the VPAC1 and VPAC2 receptors also bind vasoactive intestinal peptide with similar affinity (8-12). Early studies already pointed out the robust neuroprotective effects of PACAP in vitro and in vivo through a combination of antiapoptotic, antiinflammatory, and antioxidant effects (8-12). Neuroprotective actions have been shown, among others, in cerebellar granule cells, neuroblastoma cells, cortical neurons, and ganglionic cells against different toxic substances and harmful stimuli, mainly through the PAC1 receptors (9). In vivo, numerous animal models have been used to establish the potential neuroprotective effects of PACAP in pathological conditions (8-12). Although originally isolated in the central nervous system and early studies showed highest concentration in the brain, PACAP has a very widespread occurrence also in peripheral organs. Numerous studies have provided proof that PACAP exerts protective effects not only in the nervous system but also in many peripheral cell types and organs. The neuroprotective effects have been reviewed several times (8-16) but the peripheral protective effects of the neuropeptide have not been summarized in a review so far. Therefore, the aim of our present paper is to review the general cytoprotective effects of PACAP in non-neuronal cell types, peripheral tissues and organs (summarized in Figure 1, Tables 1, 2).

\section{DIGESTIVE SYSTEM}

\section{Intestines}

PACAP has widespread expression in the gastrointestinal system (98-101). PACAP acts on different intestinal processes including motility (102), intestinal secretion of growth factors (103), and activity of interstitial Cajal cells (104). In vitro investigations of PACAP in small intestine were carried out using INT407 cells originally obtained from human embryonal jejunum and ileum (17). PACAP showed protective effects against oxidative stress, but it was not effective in $\mathrm{CoCl}_{2}$-induced in vitro hypoxia. Surprisingly, if cells were exposed to gamma irradiation, PACAP acted negatively on clone-forming ability, but this might be due to a function in reducing the number of damaged cells (17). Furthermore, Adcyap1 small interfering RNA transfection led to higher vulnerability in INT407 cells suggesting a protective role of endogenously present PACAP (17).

In vitro experiments using HCT-8 human colonic tumor cells revealed proliferation-enhancing effect of PACAP (105). The authors detected PACAP and specific PAC1 receptor in the
HCT-8 cell line. In addition, PACAP-38 was shown to suppress Fas receptor, suggesting a possible role of PACAP in cell survival (105). Lelievre et al. tested the effect of PACAP-27 in four human colonic adenocarcinoma cell lines (HT29, SW403, DLD1, Caco-2). They found that long-term treatment with PACAP or VIP reduced cell proliferation (106). Bacterial adhesion plays a crucial role in gastrointestinal infections. Illes et al. (107) examined the effect of PACAP on bacterial adhesion in small and large intestinal cell lines. PACAP influenced colony numbers of investigated bacteria neither in small intestinal INT407 nor in large intestinal Caco-2 cells. On the other hand, PACAP was able to act on expression of certain cytokines: it induced IL-8 and CXCL-1 activation (107).

Previous studies aimed to investigate the possible effect of PACAP in different models of intestinal pathologies. Protective effect of PACAP in a rat model of duodenal ulcer was investigated by Yagi et al. (54). Rats treated with mepirizole showed increased gastric acid secretion and hemorrhagic lesions in proximal duodenum. The applied intravenous PACAP-27 treatment led to increased $\mathrm{HCO}_{3}$ - secretion thus it could significantly reduce the severity of duodenal lesions with no effect on gastric acid secretion (54). Other studies have targeted to explore the effect of PACAP in ischemia/reperfusion. Ferencz et al. (5557) described protective effect of PACAP in a rat model of small bowel autotransplantation, modeling cold ischemia injury. Small bowel was removed and stored in standard preservation solution with or without additional PACAP. The histological damage caused by cold ischemia was ameliorated by PACAP: changes in mucous layer were reduced and crypt morphology was better preserved (55). Besides preserving the morphology, authors found that PACAP did not change lipid peroxidation but kept the endogenous scavanger capacity. Effects of endogenously present PACAP against cold ischemic injury were investigated using PACAP deficient mice (58). Cold preservation injury was established with removing small bowel from PACAP deficient and wild type animals. Histological analysis showed more severe destruction of mucous, submucous layers, and crypts in PACAP deficient mice compared to wild type animals (58). Furthermore, the effect of endogenous PACAP was also tested in warm intestinal ischemia (59). Warm intestinal ischemia was evoked by occlusion of the superior mesenteric artery. The intestinal injury indicated by tissue damage was more severe in case of mice lacking PACAP. Oxidative stress markers, like malondialdehyde have also shown significant differences between PACAP deficient and wild type animals (59).

Protective actions of PACAP were also studied in small and large intestinal inflammations (98). Heimesaat et al. (60) described protective effect of PACAP against Toxoplasma gondiiinduced acute ileitis. Both PACAP prophylaxis and treatment were effective, mice obtaining PACAP prophylaxis or treatment showed a higher survival rate (60). Authors have extended their experiments in order to investigate whether PACAP could alleviate subacute ileitis induced by low-dose Toxoplasma gondii in mice having human gut microbiota (61). PACAP treatment led to less distinct apoptotic responses in ileal and colonic epithelia. Furthermore, not only intestinal but extraintestinal 


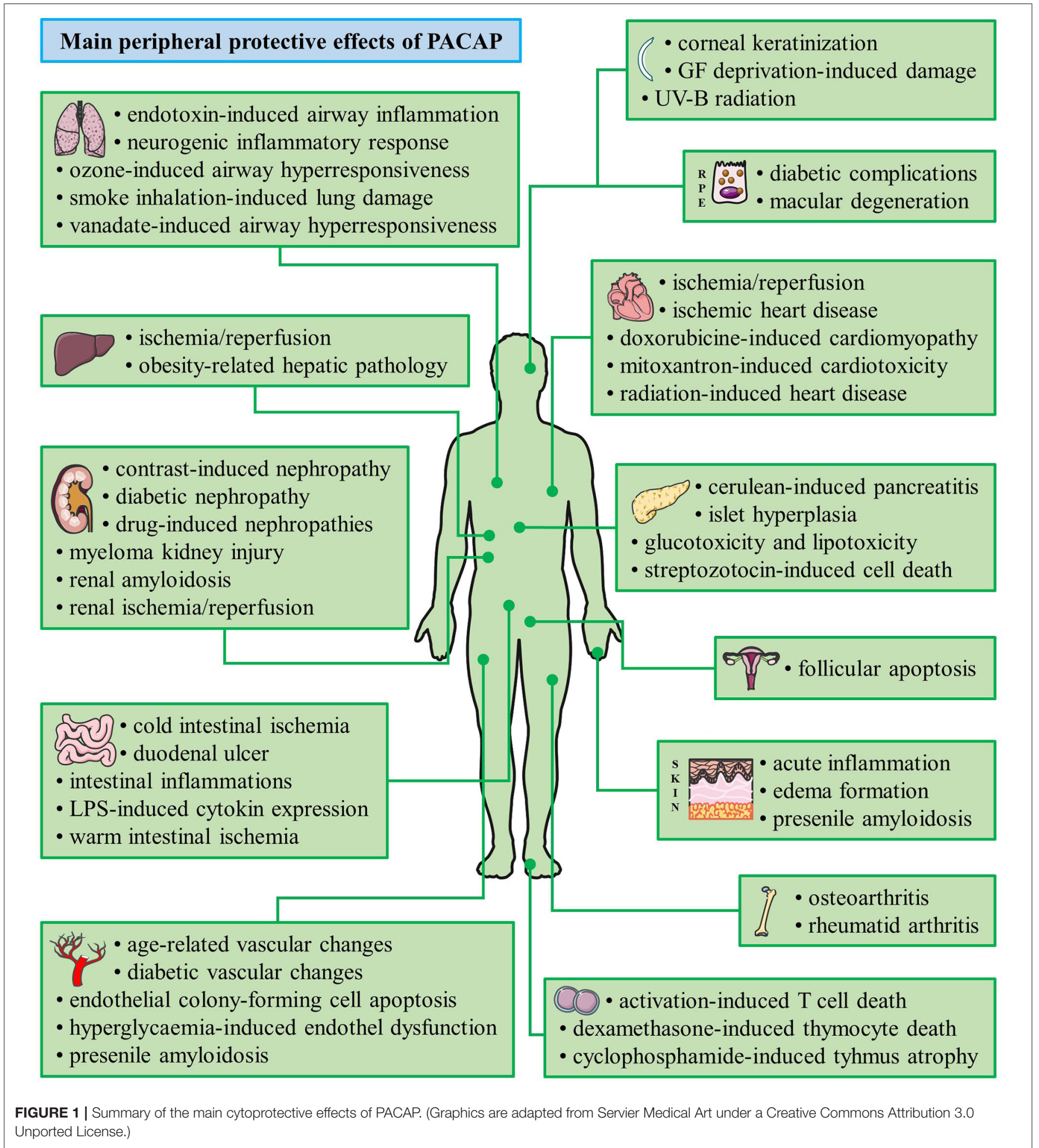

sequelae of low-dose Toxoplasma gondii infection were suppressed (61).

Effect of PACAP in large intestinal inflammation can be presumed from changes of PACAP immunoreactivity in different large intestinal pathologies in the pig (108). A considerable upregulation of PACAP mRNA level and downregulation of VPAC1 receptor were detected in transient receptor potential Ankyrin type 1 (TRPA1) knockout mice in DSS-induced colitis (109). In addition, PACAP expression was significantly reduced in transient receptor potential cation channel subfamily $\mathrm{V}$ 
TABLE 1 | In vitro studies showing protective effects of PACAP.

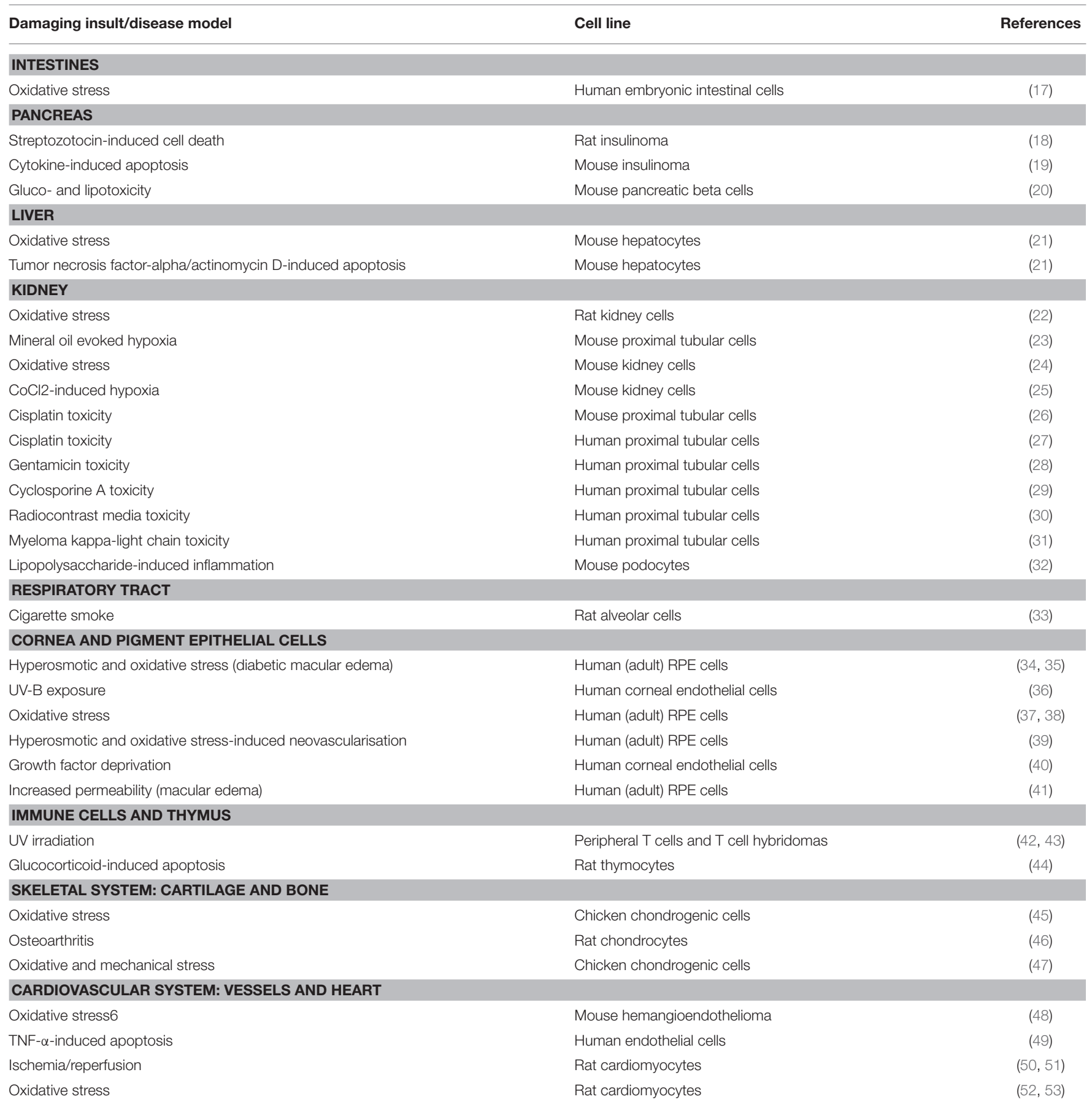

$R P E$, retinal pigment epithelium; $T N F$, tumor necrosis factor.

member 1 (TRPV-1) knockout mice, which together with reduced expression of VIP can contribute to local proinflammatory environment in these animals (110). Horvath et al. (98) investigated the possible role of PACAP in human inflammatory bowel diseases. PACAP expression was significantly higher in samples obtained from patients suffering from ulcerative colitis, while this increase could be suppressed by antibiotic therapy. Role of endogenously present PACAP was tested in dextran sulfate sodium (DSS)-induced colitis by two research groups $(62,63)$. Azuma and colleagues found, based on the histological analysis and the determination of disease activity index of PACAP knockout mice, that mice lacking PACAP had a significantly higher vulnerability than wild type controls (62). Investigations of Nemetz and coworkers 
TABLE 2 | In vivo studies showing protective effects of endogenous or exogenous PACAP.

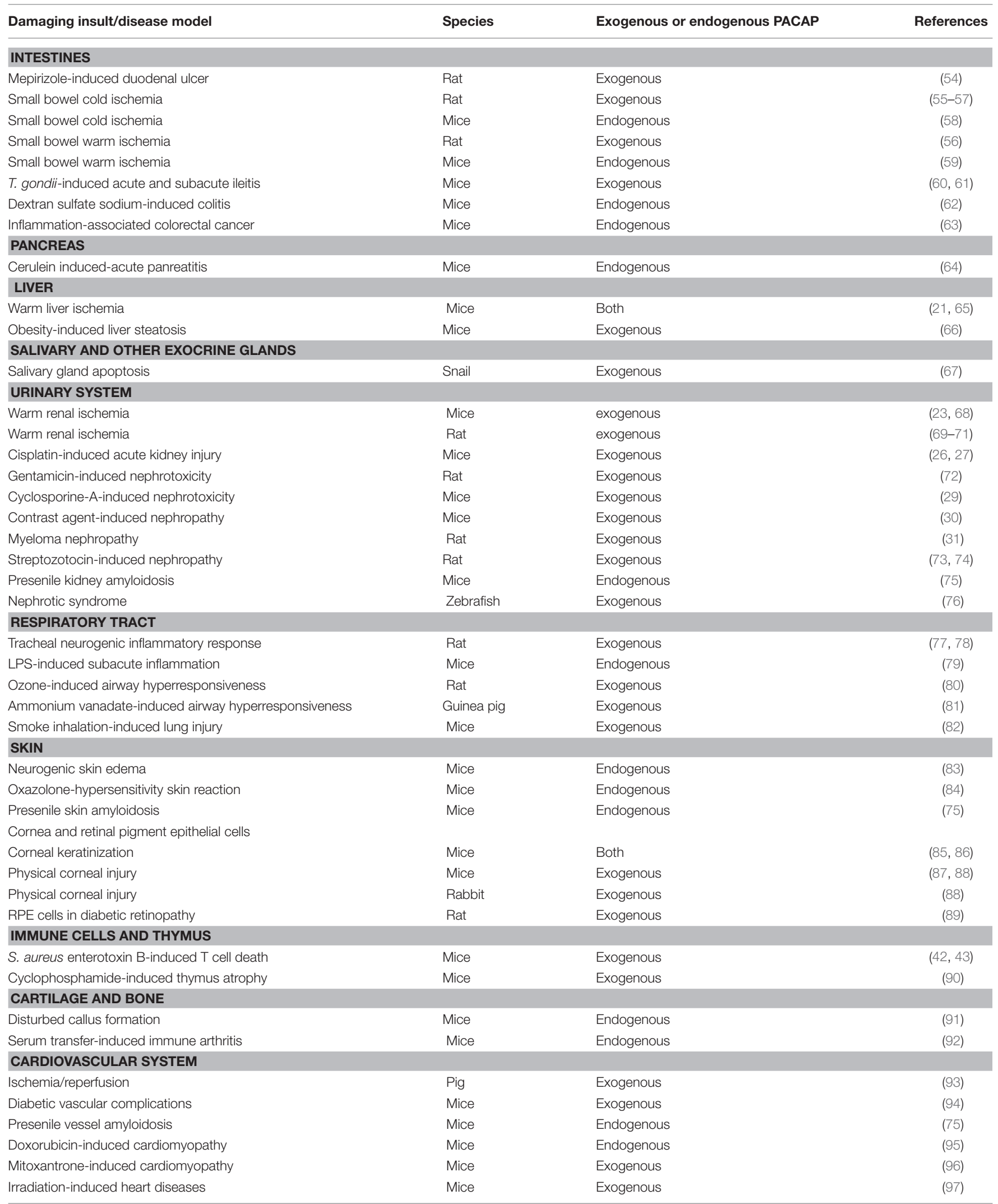

$R P E$, retinal pigment epithelium; $T N F$, tumor necrosis factor. 
supported these findings. Mice lacking PACAP displayed more severe symptoms of colitis and significantly stronger colonic inflammation. Moreover, $60 \%$ of DSS-treated PACAP deficient mice developed aggressive-appearing colorectal cancer (63). An altered microbiota composition can also be in the background of the increased vulnerability of PACAP knockout mice, as investigations of intestinal microbiota composition in wild type and PACAP deficient mice showed that Bifidobacteria were virtually absent in PACAP deficient mice, even when they were still breastfed (111).

\section{Pancreas}

PACAP is present in both the exocrine pancreas and in the endocrine islets of Langerhans and it is thought to be a potent intra-pancreatic regulator of beta cells under physiological and pathological conditions (112-114). Interestingly, ceruleininduced pancreatitits was aggravated in PACAP deficient mice (64), but pancreatic beta cells derived from rat insulinoma, key elements in pathogenesis in diabetes mellitus, were prevented from streptozotocin-induced cell death (18). Han and Wu (19) found that Adcyap1 overexpression reduced cytokine-induced apoptosis in a mouse insulinoma cell line. Moreover, pancreatic islets prepared from PACAP knockout and wild type mice showed significant differences in defense against glucotoxicity and lipotoxicity (20). Pancreatic islets cultured with high glucose or palmitate displayed severely impaired glucose-induced first phase $\mathrm{Ca}^{2+}$ increase and insulin secretion in PACAP deficient mice, but not in wild type animals (20). PACAP overexpression in KKA $\gamma$ mice suffering from diabetes type II attenuated hyperinsulinaemia and islet hyperplasia without alteration of plasma glucose, glucose tolerance and insulin tolerance (115). This was observed both in animals on normal diet and in mice kept on high-fat diet suggesting that PACAP regulates abnormal increase in islet mass and hyperinsulinaemia in type II diabetes $(115,116)$.

\section{Liver}

Few data indicate that PACAP is also protective in some pathological liver conditions. Although no effects on survival were reported in normal or tumorous human hepatocyte cells in vitro exposed to oxidative stress (22), PACAP showed protection in mouse hepatocytes in vitro exposed to oxidative stress by $\mathrm{H}_{2} \mathrm{O}_{2}$ or subjected to apoptosis-inducing TNF- $\alpha$ /actinomycin $\mathrm{D}$ treatment (21). In vivo protection was also described in ischemia/reperfusion liver injury (21). Pretreatment with PACAP27 or $381 \mathrm{~h}$ before the onset of ischemia diminished serum alanine aminotransferase levels, reduced the accumulation of neutrophils and macrophages, suppressed inflammatory chemokines (CXCL-1, CCL-2, CXCL-10) and cytokines (TNF$\alpha$, IL-1 $\beta$, IL- 6 , and IFN- $\beta$ ). The histological structure of the liver was better preserved after PACAP treatment: necrosis and apoptosis was reduced, caspase- 3 activity was decreased along with increased antiapoptotic molecule expression of bcl-2 and bcl-xL via cAMP/PKA activation. The phosphorylation, thus activation, of IкB $\alpha / \mathrm{NF}-\kappa \mathrm{B}$ - 65 proteins was reduced and toll-like receptor four immune response was inhibited (21).
The role of endogenous PACAP in liver protection was examined in PACAP deficient mice. Ischemia/reperfusion injury was augmented in animals lacking endogenous PACAP: serum alanin aminotransferase levels were increased and more severe tissue damage, indicated by edema, hemorrhage, congestion, and hepatocellular necrosis, was observed compared to wild type mice (21). In wild type mice, ischemic injury followed by reperfusion led to a transient drop in endogenous PACAP mRNA expression followed by a progressive increase. Similarly, ischemic reperfusion injury triggered changes in the receptor expression: VPAC receptor expression was also increased after an initial drop, while PAC1 receptor expression was increased from the onset of the ischemic period (21). A follow-up study demonstrated that the protective effects of PACAP in hepatic ischemia/reperfusion are partially mediated by induction of Yesassociated protein, a cellular modulator of tissue regeneration (65). The ischemia-induced induction of this protein was absent in mice lacking endogenous PACAP, while PACAP substitution enhanced its expression.

A recent paper showed that PACAP can alleviate inflammation and steatosis, thus it can be protective in obesity-related hepatic pathology and can ameliorate glucose and lipid metabolism (66). These effects were mainly mediated by the specific PAC1 receptor, involving Fas apoptosis inhibitory molecule (FAIM), proven both in vitro and in vivo. Lower PACAP expression was found in leukocytes isolated from obese human patients, and levels were lower in livers of obese mice. PACAP treatment of obese mice not only increased FAIM levels, but also decreased serum triglycerides and total cholesterol and reduced body weight (66). Liver triglycerides were also reduced after PACAP treatment. Systemic inflammatory markers were decreased, including MCP-1, IL-6, and TNF- $\alpha$. Examining fat tissue revealed that PACAP treatment reduced the size of adipocytes and attenuated liver steatosis. Altogether, these data indicate that PACAP ameliorates hepatic metabolism and inflammation in obesity (66). An indirect mechanism has also been suggested to play a role in the regeneration-stimulating effect of PACAP: the PACAP-regulated selenoproteine expression is strongly stimulated in liver cells during the regenerative process that occurs after partial hepatectomy (117).

\section{Salivary and Other Exocrine Glands}

Occurrence of PACAP and receptors has been shown in several exocrine glands and their secretions, including salivary, mammary and lacrimal gland $(85,114,118-121)$. Among others, PACAP enhances salivary and lacrimal gland secretion, increases salivary gland blood flow, and is implicated in breast cancer growth $(85,118,122-125)$. In contrast to the general cytoprotective effects of PACAP, in MCF-7 breast cancer cell line PACAP induced reactive oxygen species through $\mathrm{H}_{2} \mathrm{O}_{2}$ production, induced calcium release, and promoted apoptosis by increasing Bax and decreasing bcl-2 expression (126). The evolutionarily conserved nature of the antiapoptotic effect has been proven in molluscan salivary gland (67). PACAP induced a significant elevation of cAMP level in salivary gland extracts and attenuated the apoptosis-inducing effect of dopamine and colchicine, shown by the reduced caspase-positive cells (67). 


\section{URINARY SYSTEM}

Widespread distribution of PACAP and its receptors has been described in the kidney and lower urinary tract $(127,128)$, where PACAP plays distinct roles in the micturition pathways, blood supply, hormone production and inflammation (128-130). Direct protective effects of PACAP have mainly been described in the kidney, its nephroprotective actions have been widely studied. Its protective effects could be observed in different models of renal pathological conditions (131). It shows protective effects both in vitro and in vivo. In vitro data are available proving the renoprotective effect of PACAP in different models of cellular damage. It was shown to decrease the cell survival worsening effect of oxidative stress in primary renal cell cultures (22). In addition, Li et al. described its protection against mineral oil evoked in vitro hypoxia in proximal tubule epithelial cells obtained from wild type and MyD88 deficient mice (23). Furthermore, its endogenous action against oxidative stress and hypoxia can also be observed using PACAP deficient mice, responding with higher vulnerability to oxidative stress leading to decreased survival rate (24). Similarly, this susceptibility could also be detected when renal cells were exposed to $\mathrm{CoCl}_{2}$-evoking in vitro hypoxia (25). Experiments investigating the effect of PACAP against proteinuria mimicking albumin treatment in human proximal tubule cells showed that PACAP could not influence cell viability either positively or negatively (132). It was not able to change the increased TGF- $\beta 1$ expression either.

In vivo observations were obtained from a series of experiments modeling renal ischemia/reperfusion injury. The first experiments proving PACAP's renoprotective effect in ischemia/reperfusion were performed by Riera et al. (69). They found that continuous PACAP infusion improved renal function, attenuated morphological damage, and influenced inflammatory cellular infiltration. In addition, Szakaly et al. performed experiments, in which PACAP was able to ameliorate tubular damage and the level of oxidative stress, thus to decrease mortality of rats that underwent ischemia/reperfusion (70). PACAP was shown to reverse the cytokine expression profile after ischemic injury (133). Such renoprotective effect was also detected in mice $(23,26,27)$. Khan et al. (68) performed experiments to investigate the involvement of toll-like receptors. Dozens of toll-like receptor genes changed after ischemia, while PACAP was able to reverse these changes. Gender-dependence was investigated in a recent study comparing renoprotective effect of PACAP in male and female rats (71). Tubular alteration was markedly less severe in female rats. Female animals showed better results in both PACAP-treated and vehicle-treated experimental groups indicating the presence of several additional protective factors in females.

Actions of PACAP have also been studied in different models of drug-induced nephropathies. PACAP was able to diminish the nephrotoxic effect of gentamicin both in vitro and in vivo. In vitro experiments showed its cell survival enhancing effect in human proximal tubule cell line (HK-2) assessed by cytotoxicity assay (28). In the same experimental model, it could counteract the downregulating effect of gentamicin on dipeptidyl peptidase IV and vascular endothelial growth factor (28). In accordance with in vitro data, in vivo investigations have also explored its protective effect in gentamicin-induced nephropathy. Tubular damage caused by the accumulation of gentamicin could be attenuated by repeated intravenous administration of PACAP in rats, as indicated by the decreased TNF- $\alpha$ production (72). Chemotherapeutic agents, like cisplatin, can also lead to renal injury (134). In vitro studies using human HK-2 cells proved that PACAP protected against cisplatin-induced injury, decreased the cisplatin-induced TNF- $\alpha$ activation, influenced signaling pathways activated by cisplatin (27). Li et al. examined primary mouse renal proximal tubular epithelial cell culture (26). In accordance with results in human cells, PACAP's protective effect was detectable. In vitro results were supported by in vivo renoprotection in a mouse model of cisplatin-induced nephrotoxicity (26). Mice treated with PACAP showed less severe decrease of renal function. Furthermore, PACAP treatment was able to alleviate morphological damage and reverse the cisplatin-induced p53 activation. A further drug, cyclosporine A has also been widely studied. Cylosporine A, a potent immunosuppressant used for preventing allograft rejection and in treatment of autoimmune diseases, can also lead to impaired renal function (135). Khan et al. (29) investigated the effect of $\mathrm{PACAP}$ against cyclosporine A both in vitro and in vivo. PACAP was able to improve morphological changes and attenuate TGF- $\beta$ activation caused by cyclosporine A treatment in HK2 cells. In vitro data were further supported by their in vivo findings. PACAP could improve the impaired renal function with normalizing serum creatinine level. In addition, tubulointerstitial damage was diminished and changes in cell junctional markers were restored by PACAP treatment (29). Protective effect of PACAP against contrast-induced nephropathy was also tested by Khan et al. (30). PACAP could decrease the proliferationinhibiting effect of both ionic and non-ionic contrast media in HK-2 cells. If added prior to urografin, it was able to enhance cell survival of HK-2 cells. Furthermore, PACAP decreased the elevated kidney injury molecule-1 (KIM-1) expression evoked by contrast medium (30). In vivo findings complete the in vitro data. Mice pretreated with PACAP before contrast agent did not show severe tubular damage, apoptosis, increased oxidative stress or inflammatory reactions unlike animals receiving only contrast agent. A kidney biomarker assay further supported these data, as numerous markers associated with kidney injury were decreased in PACAP-treated mice (30).

Arimura et al. studied the actions of PACAP in myeloma kidney injury both in vitro and in vivo (31). In vitro myeloma kidney injury was generated with kappa light chains isolated from the urine of a patient suffering multiple myeloma. Human renal proximal tubule cells exposed to kappa light chains were protected by PACAP: it could mitigate the cellular injury and elevated expression of IL- 6 and TNF- $\alpha$. In vivo investigations in rats were in accordance with in vitro results. Rats receiving both PACAP and myeloma light chain showed reduced cytokine activation compared to animals treated only with light chain (31). In addition, effectiveness of PACAP was also examined in a single patient case study, in which it was shown to reduce free lambda light chains in urine indicating its possible therapeutic use in the future (136). Another target of investigations exploring 
renoprotective effect of PACAP is diabetic nephropathy, the leading cause of renal insufficiency (137). Sakamoto et al. used podocytes to model inflammation in diabetic nephropathy (32). PACAP was able to reduce the lipopolysaccharide-induced proinflammatory cytokine activation, ERK phosphorylation and $\mathrm{NF}-\kappa \mathrm{B}$ transnuclear localization. In vivo studies revealed protection in streptozotocin-induced diabetes in rats (73). Intraperitoneal PACAP treatment led to less severe morphological changes and reduced proinflammatory cytokine activation (73). Li et al. (72) applied continuous PACAP infusion for 2 weeks and they found that PACAP reduced the diabetic changes like proteinuria and glomerular enlargement. Molecular mechanism of PACAP-exerted protective effects was also examined in streptozotocin-induced diabetes (74). Results showed that PACAP could decrease the activation of apoptotic signaling pathways.

Investigating PACAP deficient mice, it was revealed that animals lacking endogenously present PACAP suffer from presenile systemic amyloidosis (75). Severe amyloidosis can be observed in several organs including the kidney. Kidney was one of the most affected organs, amyloid deposits were found in renal corpuscles. Level of renal function was also in accordance with amyloid deposits: serum creatinine level was increased in aging PACAP-deficient mice $(75,138)$.

PACAP suppression experiments in zebrafish of Eneman et al. revealed that nephrin depletion, a model of nephrotic syndrome is associated with adcyapla and vip downregulation (76). Using adcyapla and adcyap1b morpholinos the authors decribed more severe sequelae of nephrin depletion. In addition, administration of human PACAP38 could rescue the phenotype of zebrafish embryos injected with PACAP morpholino, but it was not able to save them in case of nephrin depletion. Nephrotic syndrome was also modeled by adriamycin exposure, when only adcyap 1a gene was downregulated. Furthermore, nephrotic fishes showed reduced protein expression of PACAP. PACAP morpholinos worsened the change in phenotype induced by adriamycin exposure, which could be attenuated by addition of human PACAP38 (76).

\section{RESPIRATORY TRACT}

Although the role of PACAP in the respiratory tract is not as widely studied as that of VIP, PACAP and is receptors occur in the entire length of the respiratory tract (139-141) and several effects have been described in airway smooth muscle contraction and mucous secretion (142-144). It has been reported that PACAP increases allergic reactions in the human nasal mucosa by increasing resistance and plasma leakage (145), but PAC1 receptor is implicated in anti-inflammatory reactions and mediates alleviation of bronchial hyperreactivity (146). Exogenous PACAP diminished both capsaicin- and electric field stimulation-evoked sensory neuropeptide release in a concentration-dependent manner in trachea preparations $(77,78)$, showing that PACAP is able to diminish neurogenic inflammatory response in vivo. The protective role of PACAP has also been demonstrated in a lung inflammation model of mice (79). In endotoxin-induced subacute airway inflammation, airway hyperreactivity, histopathological changes, and myeloperoxidase activity were markedly higher in mice lacking endogenous PACAP, pointing to the anti-inflammatory role of endogenous PACAP in the lungs (79). In another rat model, in vanadate-induced airway hyperresponsiveness, PACAP inhalation alleviated the increase in bronchial resistance, reduced the increased inflammatory chemokine, and cytokine release and improved the antioxidant status, also pointing to the potential of PACAP treatment in inflammatory and allergic respiratory conditions (80). Similar results were found in ozone-induced airway hyperresponsiveness, which was suppressed by PACAP without affecting plasma extravasation (81). Furthermore, Yu et al. (82) have described that PACAP, bound to a traversing-enhancing TAT peptide, can alleviate smoke inhalation-induced condition. They found that both PACAP and PACAP-TAT decreased mortality, led to a bodyweight increase, alleviated edema and vascular permeability increase, and decreased oxidative stress as indicated by reduced myeloperoxidase activity, interleukin-6, and malondyaldehyde levels while increased catalase levels in the lungs of mice that were exposed to repeated smoke inhalation (82). PACAP and PACAP-TAT treatments also resulted in decreased cell infiltration and bronchial epithelial hyperplasia. These data indicate that PACAP can alleviate smoke inhalation-induced damage of the lungs. These data confirmed earlier results showing that PACAP protected rat alveolar L2 cells from cytotoxicity of cigarette smoke by reducing caspase activity resulting in reduced apoptotic cell death (33). PACAP has also been implicated in lung cancer cell growth (147). PACAP stimulates colony formation and nuclear oncogene expression in NCI-N417 lung cancer cells, while PACAP antagonist treatment slows down small cell lung cancer growth $(148,149)$ and lower levels of PACAP were described in human lung cancer biopsies in comparison with neighboring healthy tissue (150). PACAP induces vasodilation, including pulmonary vessels. The absence of its specific receptor PAC1 causes pulmonary hypertension and right heart failure after birth (151). These findings demonstrate the crucial importance of PAC1-mediated signaling for the maintenance of normal pulmonary vascular tone during early post-natal life (151).

\section{SKIN}

The presence of PACAP and receptors has been shown in the skin $(83,152,153)$. Potent vasodilatory and edema-building effects have been attributed to cutaneous PACAP treatment soon after its discovery $(154,155)$. Recent studies have shown that PACAP stimulates sweat gland activity (156). PACAP in the skin is implicated as a protective factor in the development of inflammatory dermatological conditions, such as psoriasis $(153,157)$ and neurogenic skin inflammation (83). Although both stimulatory and inhibitory actions on skin edema formation have been described, PACAP deficient mice show increased delayed-type of hypersensitivity reaction induced by oxazolone (84). Mice lacking endogenous PACAP had increased edema 
formation, moderately enhanced cellular inflammatory reactions, and increased levels of the inflammatory cytokine monocyte chemoattractant protein-1 levels (84). These results point to the anti-allergic effects of PACAP in a model of contact dermatitis. We have already mentioned above the presenile appearance of a systemic type of amyloidosis in PACAP deficient mice $(75,138)$. The amyloid deposition was markedly present in the skin, under the epidermis. In the skin, the main location of the deposits was the dermal papillary layer, continuous with the homogeneous mass in the connective tissue surrounding appendages (hair follicles and sebaceous and sweat glands) and vessel walls. While in wild type mice occurrence of amyloidosis was observed in 57\% of the animals at old age, and only $14 \%$ young mice, already in $67 \%$ of young PACAP KO mice and nearly $90 \%$ of old PACAP KO mice exhibited amyloid deposits (75) in the skin. This shows that PACAP deficiency can be an attributing factor in skin aging.

\section{NON-NEURONAL PARTS OF THE VISUAL SYSTEM: CORNEA AND RETINAL PIGMENT EPITHELIAL CELLS}

The effects of PACAP in the visual system have been widely investigated and numerous reports have shown the effects of PACAP in the neural parts, especially in the retina. Both in vitro and in vivo studies have demonstrated that PACAP is a potent neuroprotective agent in different retinal pathologies. These effects have been reviewed in several papers $(86,158$, 159). Other, non-neuronal parts of the eye have also been investigated for the actions of PACAP. Among others, PACAP influences sphincter and dilator pupillary muscle contractility (160), increases cAMP in the ciliary epithelium (161) and is involved in ocular inflammatory reactions (162). Regarding cytoprotective effects, several studies have described that PACAP protects the cornea. The cornea consists of 5 layers, the outer epithelium building the barrier toward the outside and the inner endothelium serves as a barrier toward the aqueous humor. Both inner and outer epithelial layers play an important role in maintaining the hydration and transparency of the main stromal layer, which is separated from the outer and inner epithelial layers by outer and inner limiting membranes, respectively. PACAP receptors have been described on the surface of the cornea (85). It is thought that the peptide produced by the lacrimal gland and present in the lacrimal fluid can act on the surface of the cornea and can play a role in the regeneration of the corneal surface epithelial cells. Indeed, PACAP eye drops prevent corneal keratinization in PACAP deficient mice (85). A PACAP-derived peptide has been shown to promote corneal wound healing $(87,88)$. PACAP given in form of eye drops not only acts directly on the surface but also passes ocular barriers and is able to induce protective effects in the retina $(163,164)$.

Recent studies have reported that PACAP is protective in corneal endothelial cells, where PACAP and all three receptors are expressed $(34,35)$. In isolated human corneal endothelial cells PACAP protected growth factor deprivation-induced decrease in cellular viability and restored transepithelial electrical resistance (34). Furthermore, PACAP increased the expression of tight junction proteins and stimulated corneal endothelial repair demonstrated in a wound healing assay (34). Noteworthy, PACAP exerted a protective effect on corneal endothelium against ultraviolet $\mathrm{B}$ (UV-B) radiation, by reducing the activation of apoptotic pathway through a down-regulation of bax and cleaved caspase- 3 and up-regulation of bcl-2 protein. Moreover, PACAP preserved corneal endothelium integrity following UV$B$ exposure by increasing transepithelial electrical resistance and the expression of ZO-1 and claudin-1 proteins (36). The same authors investigated the involvement of epidermal growth factor receptor involvement in PACAP-induced protection of corneal endothelial cells (35). They found that PACAP, through $\mathrm{PAC1}$ receptor, induced epidermal growth factor receptor phosphorylation and MAP kinase/ERK1/2 activation. These results are also in accordance with data obtained in retinal pigment epithelial cells where PACAP restored cell viability in pigment epithelial cells exposed to different stressors, induced ERK and epidermal growth factor receptor phosphorylation and ameliorated junctional protein damage (37-40).

The retinal pigment epithelium is the outermost, non-neural layer of the retina. The apical surface of the cells is in contact with the outer segments of the photoreceptor cells, while the basolateral surface attaches to the Bruch's membrane, which separates the pigment cells from the choriocapillary layer. Tight junctions interconnecting retinal pigment cells are the main components of the outer blood-retina barrier, which has essential roles in the maintenance of the retinal homeostasis. Dysfunction of the tight junctions has been observed in diabetes and ischemia, leading to leakage of macromolecules into the retina, contributing to the development of retinopathies (165). Retinal pigment epithelial cells are likely to undergo hyperosmotic stress during the development of macular edema, resulting in reduction in aquaporin-4 expression (166). Moreover, hyperosmolarity was observed to induce transcription of bFGF and HB-EGF genes and secretion of bFGF from the pigment cells (167). One of the most important factors secreted by the pigment epithelial cells is vascular endothelial growth factor, VEGF (168172). Overexpression of VEGF is one of the major inducers of age related macular degeneration and proliferative diabetic retinopathy, which are among the leading causes of blindness worldwide (173).

All three PACAP receptors (PAC1, VPAC1, and VPAC2) mRNAs were detectable in the pigment epithelium (174). According to Mester et al. (37) adult retinal pigment epithelial cells (ARPE-19) exposed to $\mathrm{H}_{2} \mathrm{O}_{2}$ could be rescued with PACAP in a dose-dependent manner. In a subsequent study it was also proved that PACAP could inhibit the expression of proapoptotic factors (Bad, Bax, and Hifl $\alpha$ ) and elevate the levels of anti-apoptotic factors such as ERK1/2 and CREB (38). Besides its general cell protective, pro-survival, and anti-inflammatory effects, PACAP possesses protective effects on tight junctions of endothelial and epithelial cells (175). PACAP was shown to have a protective effect on the barrier properties of the cells of the outer-blood-retinal barrier in the presence of factors accounting for diabetic macular edema $(34,35,41,89)$.

PACAP could also reduce the concentration of VEGF in ARPE-19 cells. Moreover, PACAP was able to attenuate 
the levels of some other pro-angiogenic proteins (uPA, angiogenin, and endothelin-1). As a conclusion, PACAP is among the emerging molecules to fight diabetic complications and macular degeneration, similarly to VEGF antagonists, antioxidants, anti-inflammatory agents, and other neuropeptides (39).

\section{IMMUNE CELLS AND THYMUS}

PACAP is a well-established modulator of innate and acquired immunity and exerts protective functions in immunological diseases, although the presence of both anti- and proinflammatory roles of PACAP depending on the immune status, disease, age, and pathological conditions complicate the immunological role of PACAP $(176,177)$. As there are several reviews on the immunomodulatory roles of PACAP (177-179), the present review summarizes only data regarding direct cellular protection in lymphatic organs and cells. Activation induced cell death in $\mathrm{T}$ lymphocytes is an important mechanism in peripheral tolerance, initiated by antigen reengagement, and mediated through Fas/Fas ligand (FasL) interactions. PACAP was found to inhibit this induced cell death in vivo and in vitro in peripheral $\mathrm{T}$ cells and $\mathrm{T}$ cell hybridomas $(42,43)$. Both forms of PACAP, PACAP27 and PACAP38, can protect CD4+CD8+ thymocytes from glucocorticoid-induced apoptosis, suggesting an involvement of PACAP in thymic T-cell maturation (44). The expression of PAC1 receptor and PACAP increased in the degenerative thymus induced by cyclophosphamide (90). The authors have also described that while high dose PACAP had no protective effects against cyclophosphamide-induced thymus atrophy, low dose PACAP promoted the thymus index, inhibited apoptosis, enhanced oxidative status, and decreased caspase activity (90).

\section{SKELETAL SYSTEM: CARTILAGE AND BONE}

Neuropeptides have important functions in the development of skeletal elements and also in regeneration processes (180, 181). Detailed analysis of PACAP receptors has been performed in chondrogenic cell cultures (45) and osteogenic cell lines $(182,183)$. The specific PAC1 receptor has been identified in bone and cartilage $(45,183)$ and the activation of PAC1 by PACAP has positive effect on cartilage and bone formation $(45,184)$ via the activation of protein kinase A (PKA)regulated pathways. PACAP also positively regulates matrix expresssion of both musculoskeletal elements. Addition of PACAP to chondrogenic cell cultures increases the activation of Sox9 (SRY-related HMG-BOX gene) and regulates the expression of HAS2 and HAS3 (hyaluronan synthase) expression (45). In bone PACAP increased the activation of alkaline phosphatase (ALP) and elevated the expression of collagen type I (184).

In degenerative cartilage diseases increasing number of experiments have been performed in the last decade to prove that PACAP plays a protective role. First, it was shown that the expression of PAC1 receptor was altered in specific layers of cartilage in osteoarthritis (OA) (46) and reduced during oxidative stress (45). On the other hand, the neuropeptide has a preventive function in pathological processes. In cartilage, the antagonist PACAP6-38 behaves as an agonist and administration of both PACAP1-38 and 6-38 protected against the harmful effect of oxidative stress in high density chondrogenic cell cultures via the elevation of collagen type II, aggrecan and hyaluronic acid expression (45). PACAP elevated the activation of $\mathrm{PP} 2 \mathrm{~B}$ (protein phosphatase $2 \mathrm{~B}$ ) and subsequently triggered the activation of NFAT (Nuclear factor of activated Tcells). In oxidative stress PACAP administration prevented the phosphorylation processes of chondrogenic signaling pathways in chicken high density cultures. The administration of the neuropeptide was able to defend cartilage formation during mechanical overload via decreasing the expression of collagen type $\mathrm{X}$, a characteristic sign of OA cartilage. On the other hand, it increased collagen type II expression inducing a chondrogenic phenotype formation (185). PACAP signaling also communicates with the hedgehog pathways leading to decreased expression of $\mathrm{SHH}$ (sonic hedgehog) and $\mathrm{IHH}$ (Indian hedgehog) (185). The reduced activation of hedgehog pathways kept cartilage in a prehypertrophic condition (185) suggesting an important role of PACAP in cartilage degradation processes. Furthermore, mechanical overload and presence of reactive oxygen species trigger the activation of several matrix degrading enzymes such as matrix metalloproteinases, hyaluronidases, and aggrecanases in OA. PACAP was able to reduce the activation of matrix metalloproteinases and aggrecanases in chondrogenic cell cultures exposed to forced physical stress and oxidative stress, further strengthening the preventive function of the neuropeptide in cartilage diseases (47). In OA patients concentration of PACAP is decreased (186) and the administration of PACAP with hyaluronic acid injection increased the synovial fluid PACAP concentration and prevented the cartilage degradation processes (186). Moreover, PACAP addition during anterior cruciate ligament related OA formation can be an adjuvant therapy to prevent the physiological structure of articular cartilage (187). Taken together application of PACAP as a potential therapeutic target of OA formation is likely as it was discussed by Grassel et al. (188).

Some data point to the possible importance of PACAP in bone regeneration processes. First of all, the presence of PACAP is needed for proper bone architecture formation (184). In the lack of PACAP the long bones are more fragile and their organic and inorganic extracellular matrix balance and distribution are disturbed (184). In callus formation PACAP is proven to have important function via the activation of BMP (bone morphogenetic protein) signaling pathway and balance the ALP expression (91). In mice lacking endogenous PACAP, callus formation after tibia fracture was disturbed with several alterations in compensatory pathways (91). Furthermore, PACAP has an important function in bone turnover and inflammation (92). On the other hand, the presence of PACAP inhibited osteophyte formation and had a preventive role in rheumatoid arthritis development (92). 


\section{CARDIOVASCULAR SYSTEM: VESSELS AND HEART}

PACAP is a well-known vasodilator peptide (189-191). Receptors are found in vessel walls and PACAP-induced vasodilatory effects have been demonstrated in various vessels in vitro and in vivo. This perfusion-increasing potency has beneficial effects in several organs, but can also trigger migraines through this activity in meningeal arteries $(192,193)$. PACAP has also been described to preserve post-ischemic cerebrovascular reactivity in pigs, independent of its vasodilatory effect (93). As there are several original and review papers published in the recent years regarding this vasodilatory effects of PACAP (191-196), now we focus more on the protective effects of PACAP exerted directly on the vascular wall, especially on endothelial cells. First results showed protective effects against oxidative stress: exposure of mouse hemangioendothelioma cells to hydrogen peroxide resulted in a robust reduction of viability and an increase of apoptotic cells, while co-incubation with PACAP increased cell viability and reduced the number of apoptotic cells (48). PACAP treatment also ameliorated the reduced level of ERK phosphorylation and counteracted the increased phosphorylation of the pro-apoptotic JNK and p38 MAP kinases. PACAP also exerts a cytoprotective effect on endothelial colony forming cells exposed to TNF- $\alpha$ and partially rescues their proliferation potential inhibited by prolonged TNF- $\alpha$ exposure (49). In a more recent study, ameliorating effect of PACAP has been described in hyperglycaemia-induced endothelial dysfunction, an important factor contributing to diabetes-related vascular pathology (94). PACAP reduced the hyperglycaemia-induced elevation of fibroblast growth factor basic, matrix metalloproteinase 9 and nephroblastoma overexpressed gene proteins, implicating a protective role of PACAP in vascular complications of diabetes (94). PACAP deficient mice are susceptible to develop a systemic form of senile apolipoprotein IV-predominant amyloidosis, characterized by typical perivascular deposits in most organs $(75,138)$, pointing to the role of PACAP in age-related vascular changes. This has been also confirmed in a study where angiogenic capacity was examined in cerebromicrovascular endothelial cells (197). In aged cells, expression of PACAP was decreased, associated with reduced capacity to form capillary-like structures, impaired adhesiveness to collagen, and increased apoptosis (caspase3 activity). Overexpression of PACAP in aged endothelial cells resulted in increased tube-formation capacity. Treatment with recombinant PACAP also increased tube formation and inhibited apoptosis in aged cells. In young cerebromicrovascular endothelial cells, knockdown of endogenous PACAP expression impaired tube formation capacity, mimicking the aging phenotype (197).

PACAP and its receptors occur in the heart and the neuropeptide exerts various different cardiac functions. Several studies examined the potential effects of PACAP in the cardiovascular system. The presence of this polypeptide and its PAC1 receptor have been demonstrated in cardiomyocyte cell cultures, mouse heart tissue and also in human heart samples (150, 198-200). PACAP has direct positive chronotrop, inotrop, dromotrop, and vasodilatator effects and exerts robust cardioprotective actions due to its antiapoptotic and antioxidant properties (201). The cardioprotective effects of PACAP were first identified in cardiomyocyte cell cultures against different ischemia/reperfusion injuries. In these experiments, exogenous PACAP treatment lead to decreased level of pro-apoptotic factors (Bad, caspase-3) and elevated levels of anti-apoptotic proteins (cleaved caspase-8, Bcl-xl) inducing significantly increased cell viability $(50,51)$. Moreover, several in vitro experiments have already proven that PACAP provides effective protection against oxidative stress induced apoptosis due to higher Bcl2 and phospho-Bad expression and lower caspase or Jun Nterminal kinase and p38 mitogen activated protein (MAP) kinase activation (51-53).

Besides in vitro researches, different animal studies also examined the cardioprotective effects of PACAP. Alston et al. detected significantly higher endogenous PACAP levels and mRNA expression in mice after myocardial infarction (202). Furthermore, examining doxorubicine induced cardiomyopathy, significantly more severe DNA damage and apoptotic cell death were detected in PACAP-deficient mice compared to wild types (95). In another study, PACAP treatment had protective effect against mitoxandron induced cardiotoxicity (96). PACAP attenuated body weight reduction of mice, prevented mitoxantrone-induced left ventricular dilation resulting in diminished functional deterioration shown by the ejection fraction and fractional shortening (96). A recent study provided both in vitro and in vivo evidence that PACAP attenuates radiation-induced heart disease, a common consequence of thoracic irradiation therapy (97). PACAP enhanced viability and colony-forming efficiency, while reduced generation of reactive oxygen species in cardiomyocytes exposed to radiation. PACAP exposure suppressed myocardial apoptosis and G2/M arrest through blunting the radiation-induced down-regulation of $\mathrm{Bcl}-2$, CyclinB1 and $\mathrm{CDC} 2$, and inhibiting the up-regulation of Bax (97). Pre-treatment with PACAP also protected mice from radiation-induced histological damage including myocardial apoptosis and fibrosis (97).

In addition to the several in vitro and animal experiments, a few human studies have also been performed that raise the possibility of PACAP being cardioprotective also in the human heart. Szanto et al. examined human right auricle tissue samples from coronary artery bypass or heart valve implantation surgery. They found significantly higher PACAP concentration in patients with ischemic heart disease compared to valvular abnormalities emphasizing the protective role of PACAP in ischemic heart diseases (150). Remarkable differences were detected in plasma PACAP levels of ischemic and primary dilated cardiomyopathy patients. A significant negative correlation was observed between the severity of ischemic heart failure and plasma PACAP levels suggesting that PACAP might play an important role in the pathomechanism and progression of ischemic heart failure (203). Lack of PAC1-mediated signaling has been shown to be associated with pulmonary hypertension and right heart failure in PAC1 deficient mice, indicating the crucial importance 
of PACAP in the maintenance of normal pulmonary vascular tone (151).

\section{REPRODUCTIVE ORGANS}

PACAP and its receptors have widespread and stage-specific occurrence in the gonads and their presence have been shown in several other reproductive organs $(100,204,205)$. PACAP has been described as a follicle-surviving factor due to suppression of apoptosis in a dose-dependent manner in rat ovaries (206). Although PACAP has been detected in the human ovarian follicular fluid, its exact role in the human ovary is not known (207). In the testis, PACAP plays a role in spermatogenesis and is supposed to be involved in tumor growth $(100,208$, 209). Interestingly, in spite of PACAP deficient mice displaying disturbed spermatogenesis and altered testicular immunity (100, 210), they also show delayed testicular aging supposedly due to the stimulatory effect of PACAP on testosterone production, which, in turn, accelerates aging due to increased oxidative stress (211). The involvement of PACAP has been described in numerous reproductive processes from fertilization to implantation (212-214). However, its direct cytoprotective effects have only been shown in a few cases. PACAP protects human trophoblast cells against oxidative stress, but has no effect against methotrexate-induced cell death and in contrast, it potentiates cell death in choriocarcinoma cells $(205,215,216)$. Similar tumor cell growth inhibiting effects have been described in cervical cancer cells (217). These data demonstrate that while in many tissues PACAP is clearly a pro-survival factor, no such clear effect has been found in the reproductive tissues, where PACAP seems to play a more complex regulatory role in reproductive processes and during tumor growth.

\section{OTHER CELL TYPES}

One study described that PACAP was able to attenuate apoptosis of human hypophysis adenoma cell line HP75 induced by transforming growth factor- $\beta 1$ (218). In PC3 human prostate cancer cells PACAP inhibited apoptosis induced by serum starvation (219). PACAP alone did not influence cell survival in cultured pinealocytes, but could attenuate the toxic effect of $\mathrm{H}_{2} \mathrm{O}_{2}$. However, co-incubation of pinealocytes with PACAP promoted survival only in the dark phase, PACAP during the light phase did not result in significant differences in the percentage of living cells. This suggests that the time of day can also influence the protective effects of PACAP (220). PACAP inhibited serum depletion-induced apoptosis of megakaryocytes via VPAC1 stimulation (221).

\section{CONTRADICTORY ASPECTS}

Based on the studies summarized here PACAP is now considered as a general cytoprotective peptide. However, its cell survivalpromoting effect depends on a number of factors. First of all, it depends on the type of cell and developmental stage of a cell type. Also, numerous other factors can influence whether PACAP acts as a pro-survival factor, has no effect, or even on the contrary, it induces cell death (222). For example, PACAP has been described to counteract the cytotoxic effects of cisplatin chemotherapy treatment in neurons, without affecting the toxic effects in ovarian cells, thereby not influencing the therapeutic effect of cisplatin on tumor cells (223). Glioblastoma cell invasion is inhibited by PACAP under low oxygen tension (224), while both pro- and anti-proliferative effects have been found in different glioblastoma cell lines $(225,226)$. As we summarized the cytoprotective effects of the peptide present in several cell types, PACAP has also been described to exert cytotoxic effects in high doses in certain tumor cells, like in retinoblastoma cells (227). In certain cells, neither pro- nor anti-survival effects could be found, like JAR cytotrophoblast cells with or without methotrexate treatment (205) or in HEP-G2 hepatocellular carcinoma cells subjected to oxidative stress (22). In contrast, in several other tumor cell line, PACAP has been shown to inhibit growth, like MCF-7 breast cancer cells (126), a negative regulator of cervical carcinoma as overexpression of the PACAP gene in cervical cancer cell lines lacking PACAP expression significantly inhibited cell growth and induced apoptosis (217), is a pro-apoptotic factor in choriocarcinoma cells (215), and inhibits the growth of myeloma, leukemia and medulloblastoma cells (228-230).

\section{SUMMARY}

In summary, PACAP has protective effects against various harmful stimuli in a wide range of tissues in the periphery. Numerous factors influence this protective effect, the detailed mapping of which awaits further investigatons.

\section{AUTHOR CONTRIBUTIONS}

DT and DR conceptualized the paper. DT and VV constructed the figure. AT, ES, TJ, GH, EF, BO, DS, GM, AD'A, and VD'A wrote parts of the review.

\section{ACKNOWLEDGMENTS}

The authors acknowledge MTA-TKI 14016, K119759, EFOP3.6.2-16-2017-00008: The role of neuro-inflammation in neurodegeneration: from molecules to clinics/Center for Neuroscience, PTE AOK Research Grants KA-201717, KA-2016-03, 2017-1.2.1-NKP-2017-00002 NAP2, GINOP-2.3.2-15-2016-00050 PEPSYS EFOP-3.6.1.-16-201600004-Comprehensive Development for Implementing Smart Specialization Strategies at the University of Pécs, Higher Education Institutional Excellence Program of the Ministry of Human Capacities in Hungary, within the framework of the FIKPII, EFOP-3.6.3-VEKOP-16-2017-00009, and University of Debrecen Bridging Fund PTE-KA-2019-30. 


\section{REFERENCES}

1. Miyata A, Arimura A, Dahl RR, Minamino N, Uehara A, Jiang L, et al. Isolation of a novel 38 residue-hypothalamic polypeptide which stimulates adenylate cyclase in pituitary cells. Biochem Biophys Res Commun. (1989) 164:567-74. doi: 10.1016/0006-291X(89)91757-9

2. Nguyen TT, Kambe Y, Kurihara T, Nakamachi T, Shintani N, Hashimoto $\mathrm{H}$, et al. Pituitary adenylate cyclase-activating polypeptide in the ventromedial hypothalamus is responsible for food intake behavior by modulating the expression of agouti-related peptide in mice. Mol Neurobiol. (2020) 57:2101-114. doi: 10.1007/s12035-019-01 864-7

3. Miles OW, May V, Hammack SE. Pituitary Adenylate Cyclase-Activating Peptide (PACAP) signaling and the dark side of addiction. J Mol Neurosci. (2019) 68:453-64. doi: 10.1007/s12031-018-1147-6

4. Cline DL, Short LI, Forster MAM, Gray SL. Adipose tissue expression of PACAP, VIP, and their receptors in response to cold stress. J Mol Neurosci. (2019) 68:427-38. doi: 10.1007/s12031-018-1099-x

5. Mijiddorj T, Kanasaki H, Oride A, Hara T, Sukhbaatar U, Tumurbaatar $\mathrm{T}$, et al. Interaction between kisspeptin and adenylate cyclase-activating polypeptide 1 on the expression of pituitary gonadotropin subunits: a study using mouse pituitary lbetaT2 cells. Biol Reprod. (2017) 96:1043-51. doi: 10.1093/biolre/iox030

6. Koves K. Presence and role of PACAP in endocrine glands of mammals. In: Reglodi D, Tamas A, editors. Pituitary Adenylate Cyclase Activating Polypeptide - PACAP, Current Topics in Neurotoxicity 11. New York, NY: Springer Nature (2016). p. 161-78.

7. Kanasaki H, Oride A, Tselmeg M, Sukhbaatar U, Kyo S. Role of PACAP and its PACAP type I receptor in the central control of reproductive hormones. In: Reglodi D, Tamas A, editors. Pituitary Adenylate Cyclase Activating Polypeptide - PACAP, Current Topics in Neurotoxicity 11. New York, NY: Springer Nature (2016). p. 375-87.

8. Somogyvari-Vigh A, Reglodi D. Pituitary adenylate cyclase activating polypeptide: a potential neuroprotective peptide. Curr Pharm Des. (2004) 10:2861-89. doi: 10.2174/1381612043383548

9. Reglodi D, Tamas A, Jungling A, Vaczy A, Rivnyak A, Fulop BD, et al. Protective effects of pituitary adenylate cyclase activating polypeptide against neurotoxic agents. Neurotoxicology. (2018) 66:185-94. doi: 10.1016/j.neuro.2018.03.010

10. Reglodi D, Kiss P, Lubics A, Tamas A. Review on the protective effects of PACAP in models of neurodegenerative diseases in vitro and in vivo. Curr Pharm Des. (2011) 17:962-72. doi: 10.2174/138161211795589355

11. Vaudry D, Falluel-Morel A, Bourgault S, Basille M, Burel D, Wurtz $\mathrm{O}$, et al. Pituitary adenylate cyclase-activating polypeptide and its receptors: 20 years after the discovery. Pharmacol Rev. (2009) 61:283-357. doi: 10.1124/pr.109.001370

12. Lee EH, Seo SR. Neuroprotective roles of pituitary adenylate cyclaseactivating polypeptide in neurodegenerative diseases. BMB Rep. (2014) 47:369-75. doi: 10.5483/BMBRep.2014.47.7.086

13. Shioda S, Nakamachi T. PACAP as a neuroprotective factor in ischemic neuronal injuries. Peptides. (2015) 72:202-7. doi: 10.1016/j.peptides.2015.08.006

14. Manecka D-L, Boukhzar L, Falluel-Morel A, Lihrmann I, Anouar Y. PACAP signaling in neuroprotection. In: Reglodi D, Tamas A, editors. Pituitary Adenylate Cyclase Activating Polypeptide - PACAP, Current Topics in Neurotoxicity 11. New York, NY: Springer Nature (2016). p. 549-61.

15. Brifault C, Vaudry D, Wurtz O. The neuropeptide PACAP, a potent disease modifier candidate for brain stroke treatment. In: Reglodi D, Tamas A, editors. Pituitary Adenylate Cyclase Activating Polypeptide - PACAP, Current Topics in Neurotoxicity 11. New York, NY: Springer Nature (2016). p. 583606.

16. Ohtaki H, Nakamachi T, Dohi K, Shioda S. Role of PACAP in ischemic neural death. J Mol Neurosci. (2008) 36:16-25. doi: 10.1007/s12031-008-9077-3

17. Illes A, Opper B, Reglodi D, Kerenyi M, Czetany P, Boronkai A, et al. Effects of pituitary adenylate cyclase activating polypeptide on small intestinal INT 407 cells. Neuropeptides. (2017) 65:106-13. doi: 10.1016/j.npep.2017.07.002

18. Onoue S, Hanato J, Yamada S. Pituitary adenylate cyclase-activating polypeptide attenuates streptozotocin-induced apoptotic death of RIN-m5F cells through regulation of Bcl-2 family protein mRNA expression. FEBS J. (2008) 275:5542-51. doi: 10.1111/j.1742-4658.2008.06672.x

19. Han B, Wu J. DcR3 protects islet $\beta$ cells from apoptosis through modulating Adcyap1 and bank1 expression. J Immunol. (2009) 183:8157-66. doi: 10.4049/jimmunol.0901165

20. Nakata M, Shintani N, Hashimoto H, Baba A, Yada T. Intra-islet PACAP protects pancreatic $\beta$-cells against glucotoxicity and lipotoxicity. $J \mathrm{Mol}$ Neurosci. (2010) 42:404-10. doi: 10.1007/s12031-010-9383-4

21. Ji H, Zhang Y, Shen X, Gao F, Huang CY, Abad C, et al. Neuropeptide PACAP in mouse liver ischemia and reperfusion injury: immunomodulation by the cAMP-PKA pathway. Hepatology. (2013) 57:1225-37. doi: 10.1002/hep. 25802

22. Horvath G, Brubel R, Kovacs K, Reglodi D, Opper B, Ferencz A, et al. Effects of PACAP on oxidative stress-induced cell death in rat kidney and human hepatocyte cells. J Mol Neurosci. (2011) 43:67-75. doi: 10.1007/s12031-010-9428-8

23. Li M, Khan AM, Maderdrut JL, Simon EE, Batuman V. The effect of PACAP38 on MyD88-mediated signal transduction in ischemia/hypoxia-induced acute kidney injury. Am J Nephrol. (2010) 32:522-32. doi: 10.1159/000321491

24. Horvath G, Mark L, Brubel R, Szakaly P, Racz B, Kiss P, et al. Mice deficient in pituitary adenylate cyclase activating polypeptide display increased sensitivity to renal oxidative stress in vitro. Neurosci Lett. (2010) 469:70-4. doi: 10.1016/j.neulet.2009.11.046

25. Horvath G, Racz B, Szakaly P, Kiss P, Laszlo E, Hau L, et al. Mice deficient in neuropeptide pacap demonstrate increased sensitivity to in vitro kidney hypoxia. Transplant Proc. (2010) 42:2293-5. doi: 10.1016/j.transproceed.2010.05.015

26. Li M, Balamuthusamy S, Khan AM, Maderdrut JL, Simon EE, Batuman V. Pituitary adenylate cyclase-activating polypeptide prevents cisplatin-induced renal failure. J Mol Neurosci. (2011) 43:58-66. doi: 10.1007/s12031-010-9394-1

27. Li M, Balamuthusamy S, Khan AM, Maderdrut JL, Simon EE, Batuman V. Pituitary adenylate cyclase-activating polypeptide ameliorates cisplatin-induced acute kidney injury. Peptides. (2010) 31:592-602. doi: 10.1016/j.peptides.2009.12.018

28. Horvath G, Reglodi D, Czetany P, Illes A, Reman G, Fekete A, et al. Effects of pituitary adenylate cyclase activating polypeptide in human proximal tubule cells against gentamicin toxicity. Int J Pept Res Ther. (2019) 25:257-64. doi: 10.1007/s10989-017-9666-5

29. Khan AM, Li M, Brant E, Maderdrut JL, Majid DSA, Simon EE, et al. Renoprotection with pituitary adenylate cyclase-activating polypeptide in cyclosporine a-induced nephrotoxicity. J Investig Med. (2011) 59:793-802. doi: 10.2310/JIM.0b013e31821452a2

30. Khan AM, Maderdrut JL, Li M, Toliver HL, Coy DH, Simon EE, et al. Pituitary adenylate cyclase-activating polypeptide prevents contrast-induced nephropathy in a novel mouse model. Physiol Rep. (2013) 1:e00163. doi: $10.1002 /$ phy2.163

31. Arimura A, Li M, Batuman V. Potential protective action of pituitary adenylate cyclase-activating polypeptide (PACAP38) on in vitro and in vivo models of myeloma kidney injury. Blood. (2006) 107:661-8. doi: 10.1182/blood-2005-03-1186

32. Sakamoto $\mathrm{K}$, Kuno $\mathrm{K}$, Takemoto $\mathrm{M}$, He $\mathrm{P}$, Ishikawa $\mathrm{T}$, Onishi $\mathrm{S}$, et al. Pituitary adenylate cyclase-activating polypeptide protects glomerular podocytes from inflammatory injuries. J Diabetes Res. (2015) 2015:727152. doi: 10.1155/2015/727152

33. Onoue S, Endo K, Ohmori Y, Yamada S, Kimura R, Yajima T, et al. Longacting analogue of vasoactive intestinal peptide, [R15, 20, 21, L17]-VIP-GRR (IK312532), protects rat alveolar L2 cells from the cytotoxicity of cigarette smoke. Regul Pept. (2004) 123:193-9. doi: 10.1016/j.regpep.2004.04.025

34. Maugeri G, D'Amico AG, Saccone S, Federico C, Cavallaro S, D'Agata V. PACAP and VIP inhibit HIF-1 $\alpha$-mediated VEGF expression in a model of diabetic macular edema. J Cell Physiol. (2017) 232:1209-15. doi: $10.1002 /$ jcp. 25616

35. Maugeri G, D'Amico AG, Gagliano C, Saccone S, Federico C, Cavallaro $S$, et al. VIP family members prevent outer blood retinal barrier damage in a model of diabetic macular edema. J Cell Physiol. (2017) 232:1079-85. doi: $10.1002 /$ jcp. 25510 
36. Maugeri G, D’Amico AG, Amenta A, Saccone S, Federico C, Reibaldi M, et al. Protective effect of PACAP against ultraviolet B radiation-induced human corneal endothelial cell injury. Neuropeptides. (2020) 79:101978. doi: 10.1016/j.npep.2019.101978

37. Mester L, Kovacs K, Racz B, Solti I, Atlasz T, Szabadfi K, et al. Pituitary adenylate cyclase-activating polypeptide is protective against oxidative stress in human retinal pigment epithelial cells. J Mol Neurosci. (2011) 43:35-43. doi: 10.1007/s12031-010-9427-9

38. Fabian E, Reglodi D, Mester L, Szabo A, Szabadfi K, Tamas A, et al. Effects of PACAP on intracellular signaling pathways in human retinal pigment epithelial cells exposed to oxidative stress. J Mol Neurosci. (2012) 48:493-500. doi: 10.1007/s12031-012-9812-7

39. Fabian E, Reglodi D, Horvath G, Opper B, Toth G, Fazakas C, et al. Pituitary adenylate cyclase activating polypeptide acts against neovascularization in retinal pigment epithelial cells. Ann N Y Acad Sci. (2019) 1455:160-72. doi: $10.1111 /$ nyas. 14189

40. Maugeri G, D’Amico AG, Castrogiovanni P, Saccone S, Federico C, Reibaldi M, et al. PACAP through EGFR transactivation preserves human corneal endothelial integrity. J Cell Biochem. (2019) 120:10097-5. doi: $10.1002 /$ jcb. 28293

41. Scuderi S, D’Amico AG, Castorina A, Imbesi R, Carnazza ML, D’Agata V. Ameliorative effect of PACAP and VIP against increased permeability in a model of outer blood retinal barrier dysfunction. Peptides. (2013) 39:119-24. doi: 10.1016/j.peptides.2012.11.015

42. Delgado M, Ganea D. Vasoactive intestinal peptide and pituitary adenylate cyclase-activating polypeptide inhibit antigen-induced apoptosis of mature $\mathrm{T}$ lymphocytes by inhibiting fas ligand expression. J Immunol. (2000) 164:1200-10. doi: 10.4049/jimmunol.164.3.1200

43. Delgado M, Ganea D. VIP and PACAP inhibit activation induced apoptosis in T lymphocytes. Ann N Y Acad Sci. (2000) 921:55-67. doi: 10.1111/j.1749-6632.2000.tb06951.x

44. Delgado M, Garrido E, Martinez C, Leceta J, Gomariz RP. Vasoactive intestinal peptide and pituitary adenylate cyclase-activating polypeptides (PACAP27) and PACAP38) protect CD4+CD8+ thymocytes from glucocorticoid-induced apoptosis. Blood. (1996) 87:5152-61. doi: 10.1182/blood.V87.12.5152.bloodjournal87125152

45. Juhasz T, Matta C, Katona E, Somogyi C, Takacs R, Gergely P, et al. Pituitary Adenylate Cyclase Activating Polypeptide (PACAP) signalling exerts chondrogenesis promoting and protecting effects: implication of calcineurin as a downstream target. PLoS ONE. (2014) 9:e91541. doi: 10.1371/journal.pone.0091541

46. Giunta S, Castorina A, Marzagalli R, Szychlinska MA, Pichler K, Mobasheri A, et al. Ameliorative effects of PACAP against cartilage degeneration. Morphological, immunohistochemical and biochemical evidence from in vivo and in vitro models of rat osteoarthritis. Int J Mol Sci. (2015) 16:5922-44. doi: $10.3390 /$ ijms 16035922

47. Szentleleky E, Szegeczki V, Karanyicz E, Hajdu T, Tamas A, Toth G, et al. Pituitary adenylate cyclase activating polypeptide (PACAP) reduces oxidative and mechanical stress-evoked matrix degradation in chondrifying cell cultures. Int J Mol Sci. (2019) 20:168. doi: 10.3390/ijms20010168

48. Racz B, Gasz B, Borsiczky B, Gallyas F, Tamas A, Jozsa R, et al. Protective effects of pituitary adenylate cyclase activating polypeptide in endothelial cells against oxidative stress-induced apoptosis. Gen Comp Endocrinol. (2007) 153:115-23. doi: 10.1016/j.ygcen.2006.12.006

49. Bian N, Du G, Ip MF, Ding J, Chang Q, Li Z. Pituitary adenylate cyclase-activating polypeptide attenuates tumor necrosis factor- $\alpha$-induced apoptosis in endothelial colony-forming cells. Biomed Reports. (2017) 7:116. doi: 10.3892/br.2017.917

50. Roth E, Weber G, Kiss P, Horvath G, Toth G, Gasz B, et al. Effects of PACAP and preconditioning against ischemia/reperfusion-induced cardiomyocyte apoptosis in vitro. Ann N Y Acad Sci. (2009) 1163:512-6. doi: 10.1111/j.1749-6632.2008.03635.x

51. Racz B, Gasz B, Gallyas F, Kiss P, Tamas A, Szanto Z, et al. PKA-Bad-14-3-3 and Akt-Bad-14-3-3 signaling pathways are involved in the protective effects of PACAP against ischemia/reperfusion-induced cardiomyocyte apoptosis. Regul Pept. (2008) 145:105-15. doi: 10.1016/j.regpep.2007.09.015

52. Gasz B, Racz B, Roth E, Borsiczky B, Ferencz A, Tamas A, et al. Pituitary adenylate cyclase activating polypeptide protects cardiomyocytes against oxidative stress-induced apoptosis. Peptides. (2006) 27:87-94. doi: 10.1016/j.peptides.2005.06.022

53. Gasz B, Racz B, Roth E, Borsiczky B, Tamas A, Boronkai A, et al. PACAP inhibits oxidative stress-induced activation of MAP kinase-dependent apoptotic pathway in cultured cardiomyocytes. Ann N Y Acad Sci. (2006) 1070:293-7. doi: 10.1196/annals.1317.029

54. Yagi K, Takehara K, Kitamura M, Takeuchi K. Effects of pituitary adenylate cyclase activating polypeptide-27 on alkaline secretory and mucosal ulcerogenic responses in rat duodenum. Life Sci. (1998) 63:317-25. doi: 10.1016/S0024-3205(98)00280-X

55. Ferencz A, Racz B, Tamas A, Reglodi D, Lubics A, Nemeth J, et al. Influence of PACAP on oxidative stress and tissue injury following small-bowel autotransplantation. J Mol Neurosci. (2009) 37:168-76. doi: 10.1007/s12031-008-9132-0

56. Ferencz A, Racz B, Tamas A, Nedvig K, Nemeth J, Kalmar-Nagy $\mathrm{K}$, et al. Changes and effect of PACAP-38 on intestinal ischemiareperfusion and autotransplantation. Transplant Proc. (2009) 41:57-9. doi: 10.1016/j.transproceed.2008.10.084

57. Ferencz A, Reglodi D, Kalmar-Nagy K, Horvath OP, Roth E, Weber $\mathrm{G}$, et al. Influence of pituitary adenylate cyclase-activating polypeptide on the activation of mitogen activated protein kinases following small bowel cold preservation. Transplant Proc. (2009) 41:60-2. doi: 10.1016/j.transproceed.2008.08.149

58. Ferencz A, Weber G, Helyes Z, Hashimoto H, Baba A, Reglodi D. Presence of endogenous PACAP-38 ameliorated intestinal cold preservation tissue injury. J Mol Neurosci. (2010) 42:428-34. doi: 10.1007/s12031-010-9352-y

59. Ferencz A, Kiss P, Weber G, Helyes Z, Shintani N, Baba A, et al. Comparison of intestinal warm ischemic injury in PACAP knockout and wild-type mice. J Mol Neurosci. (2010) 42:435-42. doi: 10.1007/s12031-010-9357-6

60. Heimesaat MM, Dunay IR, Schulze S, Fischer A, Grundmann U, Alutis $\mathrm{M}$, et al. Pituitary adenylate cyclase-activating polypeptide ameliorates experimental acute ileitis and extra-intestinal sequelae. PLOS ONE. (2014) 9:e108389. doi: 10.1371/journal.pone.0108389

61. Bereswill S, Escher U, Grunau A, Kühl AA, Dunay IR, Tamas A, et al. Pituitary adenylate cyclase-activating polypeptide-a neuropeptide as novel treatment option for subacute ileitis in mice harboring a human gut microbiota. Front Immunol. (2019) 10:554. doi: 10.3389/fimmu.2019.00554

62. Azuma YT, Hagi K, Shintani N, Kuwamura M, Nakajima H, Hashimoto H, et al. PACAP provides colonic protection against dextran sodium sulfate induced colitis. J Cell Physiol. (2008) 216:111-9. doi: 10.1002/jcp.21381

63. Nemetz N, Abad C, Lawson G, Nobuta H, Chhith S, Duong L, et al. Induction of colitis and rapid development of colorectal tumors in mice deficient in the neuropeptide PACAP. Int J Cancer. (2008) 122:1803-9. doi: $10.1002 /$ ijc. 23308

64. Sakurai Y, Shintani N, Arimori A, Hamagami K, Higuchi N, Inoue H, et al. Cerulein-induced acute pancreatitis in PACAP knockout Mice. J Mol Neurosci. (2011) 43:8-15. doi: 10.1007/s12031-010-9396-Z

65. Liu Y, Lu T, Zhang C, Xue Z, Xu J, Busuttil RW, et al. Pituitary adenylate cyclase-activating polypeptides prevent hepatocyte damage by promoting yes-associated protein in liver ischemia-reperfusion injury. Transplantation. (2019) 103:1639-48. doi: 10.1097/TP.0000000000002742

66. Xiao X, Qiu P, Gong H, Chen X, Sun Y, Hong A, et al. PACAP ameliorates hepatic metabolism and inflammation through up-regulating FAIM in obesity. J Cell Mol Med. (2019) 23:5970-80. doi: $10.1111 / \mathrm{jcmm}$. 14453

67. Pirger Z, Nemeth J, Hiripi L, Toth G, Kiss P, Lubics A, et al. PACAP has antiapoptotic effect in the salivary gland of an invertebrate species, helix pomatia. J Mol Neurosci. (2008) 36:105-14. doi: 10.1007/s12031-008-9070-x

68. Khan AM, Li M, Abdulnour-Nakhoul S, Maderdrut JL, Simon EE, Batuman V. Delayed administration of pituitary adenylate cyclaseactivating polypeptide 38 ameliorates renal ischemia/reperfusion injury in mice by modulating toll-like receptors. Peptides. (2012) 38:395-403. doi: 10.1016/j.peptides.2012.09.023

69. Riera M, Torras JM, Cruzado J, Lloberas N, Liron J, Herrero I, et al. The enhancement of endogenous cAMP with pituitary adenylate cyclaseactivating polypeptide protects rat kidney against ischemia through the modulation of inflammatory response. Transplantation. (2001) 72:1217-23. doi: 10.1097/00007890-200110150-00006 
70. Szakaly P, Kiss P, Lubics A, Magyarlaki T, Tamas A, Racz B, et al. Effects of PACAP on survival and renal morphology in rats subjected to renal ischemia/reperfusion. J Mol Neurosci. (2008) 36:89-96. doi: 10.1007/s12031-008-9064-8

71. Laszlo E, Juhasz T, Varga A, Czibere B, Kovacs K, Degrell P, et al. Protective effect of PACAP on ischemia/reperfusion-induced kidney injury of male and female rats: gender differences. J Mol Neurosci. (2019) 68:408-19. doi: 10.1007/s12031-018-1207-y

72. Li M, Maderdrut JL, Lertora JJL, Arimura A, Batuman V. Renoprotection by pituitary adenylate cyclase-activating polypeptide in multiple myeloma and other kidney diseases. Regul Pept. (2008) 25:257-64. doi: 10.1016/j.regpep.2007.09.012

73. Banki E, Degrell P, Kiss P, Kovacs K, Kemeny A, Csanaky K, et al. Effect of PACAP treatment on kidney morphology and cytokine expression in rat diabetic nephropathy. Peptides. (2013) 42:125-30. doi: 10.1016/j.peptides.2013.02.002

74. Banki E, Kovacs K, Nagy D, Juhasz T, Degrell P, Csanaky K, et al. Molecular mechanisms underlying the nephroprotective effects of PACAP in diabetes. $J$ Mol Neurosci. (2014) 54:300-9. doi: 10.1007/s12031-014-0249-z

75. Reglodi D, Jungling A, Longuespée R, Kriegsmann J, Casadonte R, Kriegsmann M, et al. Accelerated pre-senile systemic amyloidosis in PACAP knockout mice - a protective role of PACAP in age-related degenerative processes. J Pathol. (2018) 245:478-90. doi: 10.1002/path.5100

76. Eneman B, Elmonem MA, van den Heuvel LP, Khodaparast L, Khodaparast $\mathrm{L}$, van Geet $\mathrm{C}$, et al. Pituitary adenylate cyclase-activating polypeptide (PACAP) in zebrafish models of nephrotic syndrome. PLoS ONE. (2017) 12:e0182100. doi: 10.1371/journal.pone.0182100

77. Nemeth J, Reglodi D, Pozsgai G, Szabo A, Elekes K, Pinter E, et al. Effect of pituitary adenylate cyclase activating polypeptide-38 on sensory neuropeptide release and neurogenic inflammation in rats and mice. Neuroscience. (2006) 143:223-30. doi: 10.1016/j.neuroscience.2006.07.028

78. Reglodi D, Borzsei R, Bagoly T, Boronkai A, Racz B, Tamas A, et al. Agonistic behavior of PACAP6-38 on sensory nerve terminals and cytotrophoblast cells. J Mol Neurosci. (2008) 36:270-8. doi: 10.1007/s12031-008-9089-Z

79. Elekes K, Sandor K, Moricz A, Kereskai L, Kemeny A, Szoke E, et al. Pituitary adenylate cyclase-activating polypeptide plays an anti-inflammatory role in endotoxin-induced airway inflammation: in vivo study with gene-deleted mice. Peptides. (2011) 32:1439-46. doi: 10.1016/j.peptides.2011.05.008

80. Tlili M, Rouatbi S, Sriha B, Ben Rhouma K, Sakly M, Vaudry D, et al. Pituitary adenylate cyclase-activating polypeptide reverses ammonium metavanadateinduced airway hyperresponsiveness in rats. Oxid Med Cell Longev. (2015) 2015:787561. doi: 10.1155/2015/787561

81. Aizawa H, Shigyo M, Matsumoto K, Inoue H, Koto H, Hara N. PACAP reverses airway hyperresponsiveness induced by ozone exposure in guinea pigs. Respiration. (1999) 66:538-42. doi: 10.1159/000029431

82. Yu R, Guo X, Huang L, Zeng Z, Zhang $H$. The novel peptide PACAP-TAT with enhanced traversing ability attenuates the severe lung injury induced by repeated smoke inhalation. Peptides. (2012) 38:142-9. doi: 10.1016/j.peptides.2012.09.005

83. Helyes Z, Kun J, Dobrosi N, Sándor K, Németh J, Perkecz A, et al. Pituitary adenylate cyclase-activating polypeptide is upregulated in murine skin inflammation and mediates transient receptor potential vanilloid1-induced neurogenic edema. J Invest Dermatol. (2015) 135:2209-18. doi: 10.1038/jid.2015.156

84. Kemeny A, Reglodi D, Cseharovszky R, Hashimoto H, Baba A, Szolcsanyi J, et al. Pituitary adenylate cyclase-activating polypeptide deficiency enhances oxazolone-induced allergic contact dermatitis in mice. J Mol Neurosci. (2010) 42:443-9. doi: 10.1007/s12031-010-9368-3

85. Nakamachi T, Ohtaki H, Seki T, Yofu S, Kagami N, Hashimoto H, et al. PACAP suppresses dry eye signs by stimulating tear secretion. Nat Commun. (2016) 7:12034. doi: 10.1038/ncomms12034

86. Shioda S, Takenoya F, Hirabayashi T, Wada N, Seki T, Nonaka N, et al. Effects of PACAP on dry eye symptoms, and possible use for therapeutic application. J Mol Neurosci. (2019) 68:420-26. doi: 10.1007/s12031-018-1087-1

87. Wang Z, Shan W, Li H, Feng J, Lu S, Ou B, et al. The PACAP-derived peptide MPAPO facilitates corneal wound healing by promoting corneal epithelial cell proliferation and trigeminal ganglion cell axon regeneration. Int J Biol Sci. (2019) 15:2676-91. doi: 10.7150/ijbs.35630
88. Ma Y, Zhao S, Wang X, Shen S, Ma M, Xu W, et al. A new recombinant PACAP-derived peptide efficiently promotes corneal wound repairing and lacrimal secretion. Invest Opthalmol Vis Sci. (2015) 56:4336-49. doi: 10.1167 /iovs.15-17088

89. D’Amico AG, Maugeri G, Rasà DM, Bucolo C, Saccone S, Federico $C$, et al. Modulation of IL-1 $\beta$ and VEGF expression in rat diabetic retinopathy after PACAP administration. Peptides. (2017) 97:64-69. doi: 10.1016/j.peptides.2017.09.014

90. Zhang H, Yu R, Liu X, Guo X, Zeng Z. The expression of PAC1 increases in the degenerative thymus and low dose PACAP protects female mice from cyclophosphamide induced thymus atrophy. Peptides. (2012) 38:337-43. doi: 10.1016/j.peptides.2012.09.009

91. Jozsa G, Fulop BD, Kovacs L, Czibere B, Szegeczki V, Kiss T, et al. Lack of Pituitary Adenylate Cyclase-Activating Polypeptide (PACAP) disturbs callus formation. J Mol Neurosci. (2019). doi: 10.1007/s12031-019-01448-z

92. Botz B, Bolcskei K, Kereskai L, Kovacs M, Nemeth T, Szigeti K, et al. Differential regulatory role of pituitary adenylate cyclase-activating polypeptide in the serum-transfer arthritis model. Arthritis Rheumatol. (2014) 66:2739-50. doi: 10.1002/art.38772

93. Lenti L, Zimmermann A, Kis D, Olah O, Toth GK, Hegyi O, et al. PACAP and VIP differentially preserve neurovascular reactivity after global cerebral ischemia in newborn pigs. Brain Res. (2009) 1283:50-7. doi: 10.1016/j.brainres.2009.06.021

94. Solymar M, Ivic I, Balasko M, Fulop BD, Toth G, Tamas A, et al. Pituitary adenylate cyclase-activating polypeptide ameliorates vascular dysfunction induced by hyperglycaemia. Diabetes Vasc Dis Res. (2018) 15:277-85. doi: $10.1177 / 1479164118757922$

95. Mori H, Nakamachi T, Ohtaki H, Yofu S, Sato A, Endo K, et al. Cardioprotective effect of endogenous pituitary adenylate cyclase-activating polypeptide on doxorubicin-induced cardiomyopathy in mice. Circ J. (2010) 74:1183-90. doi: 10.1253/circj.CJ-09-1024

96. Subramaniam V, Chuang G, Xia H, Burn B, Bradley J, Maderdrut JL, et al. Pituitary adenylate cyclase-activating polypeptide (PACAP) protects against mitoxantrone-induced cardiac injury in mice. Peptides. (2017) 95:25-32. doi: 10.1016/j.peptides.2017.07.007

97. Li H, Cao L, Yi PQ, Xu C, Su J, Chen PZ, et al. Pituitary adenylate cyclaseactivating polypeptide ameliorates radiation-induced cardiac injury. Am J Transl Res. (2019) 11:6585-99.

98. Horvath G, Illes A, Heimesaat MM, Bardosi A, Bardosi S, Tamas A, et al. Protective intestinal effects of pituitary adenylate cyclase activating polypeptide. In: Reglodi D, Tamas A, editors. Pituitary Adenylate Cyclase Activating Polypeptide - PACAP, Current Topics in Neurotoxicity 11. New York, NY: Springer Nature (2016). p. 271-88.

99. Rytel L, Wojtkiewicz J, Snarska A, Mikołajczyk A. Changes in the neurochemical characterization of enteric neurons in the porcine duodenum after administration of low-dose salmonella enteritidis lipopolysaccharides. $J$ Mol Neurosci. (2020). doi: 10.1007/s12031-019-01473-y

100. Reglodi D, Cseh S, Somoskoi B, Fulop BD, Szentleleky E, Szegeczki V, et al. Disturbed spermatogenic signaling in pituitary adenylate cyclase activating polypeptide-deficient mice. Reproduction. (2018) 155:127-37. doi: 10.1530/REP-17-0470

101. Reglodi D, Illes A, Opper B, Schafer E, Tamas A, Horvath G. Presence and effects of pituitary adenylate cyclase activating polypeptide under physiological and pathological conditions in the stomach. Front Endocrinol (Lausanne). (2018) 9:90. doi: 10.3389/fendo.2018.00090

102. Fujimiya M, Inui A. Peptidergic regulation of gastrointestinal motility in rodents. Peptides. (2000) 20:1565-82. doi: 10.1016/S0196-9781(00)00313-2

103. Al-Qudah M, Alkahtani R, Akbarali HI, Murthy KS, Grider JR. Stimulation of synthesis and release of brain-derived neurotropic factor from intestinal smooth muscle cells by substance $\mathrm{P}$ and pituitary adenylate cyclase-activating peptide. Neurogastroenterol Motil. (2015) 27:1162-74. doi: $10.1111 / \mathrm{nmo.12604}$

104. Wu MJ, Kee $\mathrm{KH}$, Na J, Kim SW, Bae Y, Shin DH, et al. Pituitary adenylate cyclase-activating polypeptide inhibits pacemaker activity of colonic interstitial cells of cajal. Korean J Physiol Pharmacol. (2015) 19:43540. doi: 10.4196/kjpp.2015.19.5.435

105. Le SV, Yamaguchi DJ, McArdle CA, Tachiki K, Pisegna JR, Germano $\mathrm{P} . \mathrm{PAC1}$ and PACAP expression, signaling, and effect on the growth 
of HCT8, human colonic tumor cells. Regul Pept. (2002) 109:115-25. doi: 10.1016/S0167-0115(02)00194-5

106. Lelièvre V, Meunier AC, Caigneaux E, Falcon J, Muller JM. Differential expression and function of PACAP and VIP receptors in four human colonic adenocarcinoma cell lines. Cell Signal. (1998) 10:13-26. doi: 10.1016/S0898-6568(97)00067-3

107. Illes A, Horvath G, Schafer E, Kerenyi M, Karadi O, Opper B, et al. Effect of PACAP on bacterial adherence and cytokine expression in intestinal cell cultures. Int J Pept Res Ther. (2019) 25:1011-18. doi: 10.1007/s10989-018-9748-z

108. Gonkowski S, Całka J. Changes in pituitary adenylate cyclase-activating peptide 27-like immunoreactive nervous structures in the porcine descending colon during selected pathological processes. J Mol Neurosci. (2012) 48:777-87. doi: 10.1007/s12031-012-9838-x

109. Kun J, Szitter I, Kemény Á, Perkecz A, Kereskai L, Pohóczky K, et al. Upregulation of the transient receptor potential ankyrin 1 ion channel in the inflamed human and mouse colon and its protective roles. PLoS ONE. (2014) 9:e108164. doi: 10.1371/journal.pone.0108164

110. Vinuesa AG, Sancho R, García-Limones C, Behrens A, Ten Dijke P, Calzado MA, et al. Vanilloid receptor-1 regulates neurogenic inflammation in colon and protects mice from colon cancer. Cancer Res. (2012) 72:1705-16. doi: 10.1158/0008-5472.CAN-11-3693

111. Heimesaat MM, Reifenberger G, Vicena V, Illes A, Horvath G, Tamas A, et al. Intestinal microbiota changes in mice lacking pituitary adenylate cyclase activating polypeptide (PACAP) - bifidobacteria make the difference. Eur J Microbiol Immunol. (2017) 7:187-99. doi: 10.1556/1886.2017.00021

112. Borboni P, Porzio O, Pierucci D, Cicconi S, Magnaterra R, Federici M, et al. Molecular and functional characterization of Pituitary Adenylate CyclaseActivating Polypeptide (PACAP-38)/vasoactive intestinal polypeptide receptors in pancreatic $\beta$-cells and effects of PACAP-38 on components of the insulin secretory system 1. Endocrinology. (1999) 140:5530-7. doi: 10.1210/endo.140.12.7208

113. Yada T, Sakurada M, Ihida K, Nakata M, Murata F, Arimura A, et al. Pituitary adenylate cyclase activating polypeptide is an extraordinarily potent intrapancreatic regulator of insulin secretion from islet $\beta$-cells. J Biol Chem. (1994) 269:1290-3.

114. Ferencz S, Reglodi D, Kaszas B, Bardosi A, Toth D, Vekony Z, et al. PACAP and PAC1 receptor expression in pancreatic ductal carcinoma. Oncol Lett. (2019) 18:5725-30. doi: 10.3892/ol.2019.10971

115. Tomimoto S, Hashimoto H, Shintani N, Yamamoto K, Kawabata Y, Hamagami KI, et al. Overexpression of pituitary adenylate cyclase-activating polypeptide in islets inhibits hyperinsulinemia and islet hyperplasia in agouti yellow mice. J Pharmacol Exp Ther. (2004) 309:796-803. doi: 10.1124/jpet.103.062919

116. Inoue H, Shintani N, Sakurai Y, Higashi S, Hayata-Takano A, Baba A, et al. PACAP inhibits $\beta$-cell mass expansion in a mouse model of type II diabetes: persistent suppressive effects on islet density. Front Endocrinol (Lausanne). (2013) 4:27. doi: 10.3389/fendo.2013.00027

117. Tanguy Y, Falluel-Morel A, Arthaud S, Boukhzar L, Manecka DL, Chagraoui $\mathrm{A}$, et al. The PACAP-regulated gene selenoprotein $\mathrm{T}$ is highly induced in nervous, endocrine, and metabolic tissues during ontogenetic and regenerative processes. Endocrinology. (2011) 152:4322-35. doi: 10.1210/en.2011-1246

118. Matoba $Y$, Nonaka N, Takagi Y, Imamura E, Narukawa M, Nakamachi T, et al. Pituitary adenylate cyclase-activating polypeptide enhances saliva secretion via direct binding to PACAP receptors of major salivary glands in mice. Anat Rec. (2016) 299:1293-99. doi: 10.1002/ar.23388

119. Wojtkiewicz J, Juranek JK, Kowalski I, Bladowski M, Całka J, Majewski M. Immunohistochemical characterization of superior cervical ganglion neurons supplying porcine parotid salivary gland. Neurosci Lett. (2011) 500:57-62. doi: 10.1016/j.neulet.2011.05.242

120. Csanaky K, Banki E, Szabadfi K, Reglodi D, Tarcai I, Czegledi L, et al. Changes in PACAP immunoreactivity in human milk and presence of PAC1 receptor in mammary gland during lactation. J Mol Neurosci. (2012) 48:631-7. doi: 10.1007/s12031-012-9779-4

121. Csanaky K, Doppler W, Tamas A, Kovacs K, Toth G, Reglodi D. Influence of terminal differentiation and PACAP on the cytokine, chemokine, and growth factor secretion of mammary epithelial cells. J Mol Neurosci. (2014) 52:28-36. doi: 10.1007/s12031-013-0193-3

122. Tobin G, Asztély A, Edwards A V., Ekström J, Håkanson R, Sundler F. Presence and effects of pituitary adenylate cyclase activating peptide in the submandibular gland of the ferret. Neuroscience. (1995) 66:227-35. doi: 10.1016/0306-4522(94)00622-C

123. Mirfendereski S, Tobin G, Håkanson R, Ekström J. Pituitary adenylate cyclase activating peptide (PACAP) in salivary glands of the rat: origin, and secretory and vascular effects. Acta Physiol Scand. (1997) 160:15-22. doi: 10.1046/j.1365-201X.1997.00010.x

124. García-Fernández M, Collado B, Bodega G, Cortés J, Ruíz-Villaespesa A, Carmena $\mathrm{M}$, et al. Pituitary adenylate cyclase-activating peptide/vasoactive intestinal peptide receptors in human normal mammary gland and breast cancer tissue. Gynecol Endocrinol. (2005) 20:327-33. doi: 10.1080/09513590500098240

125. Sun C, Gu Y, Chen G, Du Y. Bioinformatics analysis of stromal molecular signatures associated with breast and prostate cancer. J Comput Biol. (2019) 26:1130-39. doi: $10.1089 / \mathrm{cmb} .2019 .0045$

126. Zibara K, Zeidan A, Mallah K, Kassem N, Awad A, Mazurier F, et al. Signaling pathways activated by PACAP in MCF-7 breast cancer cells. Cell Signal. (2018) 50:37-47. doi: 10.1016/j.cellsig.2018.06.009

127. Arms L, Vizzard MA. Neuropeptides in lower urinary tract function. In: Andersson KE, Michel M, editors. Urinary tract. Handbook of Experimental Pharmacology. Berlin: Springer (2011) p. 395-423. doi: 10.1007/978-3-642-16499-6_19

128. Reglodi D, Kiss P, Horvath G, Lubics A, Laszlo E, Tamas A, et al. Effects of pituitary adenylate cyclase activating polypeptide in the urinary system, with special emphasis on its protective effects in the kidney. Neuropeptides. (2012) 46:61-70. doi: 10.1016/j.npep.2011.05.001

129. Ojala J, Tooke K, Hsiang H, Girard BM, May V, Vizzard MA. PACAP/PAC1 expression and function in micturition pathways. J Mol Neurosci. (2019) 68:357-67. doi: 10.1007/s12031-018-1170-7

130. Heppner TJ, Hennig GW, Nelson MT, May V, Vizzard MA. PACAP38mediated bladder afferent nerve activity hyperexcitability and $\mathrm{Ca} 2+$ activity in urothelial cells from mice. J Mol Neurosci. (2019) 68:348-56. doi: 10.1007/s12031-018-1119-x

131. Horvath, Opper, Reglodi D. The neuropeptide Pituitary Adenylate CyclaseActivating Polypeptide (PACAP) is protective in inflammation and oxidative stress-induced damage in the kidney. Int J Mol Sci. (2019) 20:4944. doi: $10.3390 /$ ijms 20194944

132. Eneman B, van den Heuvel L, Freson K, Van Geet C, Willemsen B, Dijkman $\mathrm{H}$, et al. Distribution and function of PACAP and its receptors in the healthy and nephrotic kidney. Nephron. (2016) 132:301-311. doi: 10.1159/000445035

133. Horvath G, Racz B, Reglodi D, Kovacs K, Kiss P, Gallyas F, et al. Effects of PACAP on mitochondrial apoptotic pathways and cytokine expression in rats subjected to renal ischemia/reperfusion. J Mol Neurosci. (2010) 42:411-8. doi: 10.1007/s12031-010-9342-0

134. Yao $\mathrm{X}$, Panichpisal $\mathrm{K}$, Kurtzman $\mathrm{N}$, Nugent K. Cisplatin nephrotoxicity: a review. Am J Med Sci. (2007) 334:115-24. doi: 10.1097/MAJ.0b013e31812dfele

135. Young EW, Ellis CN, Messana JM, Johnson KJ, Leichtman AB, Mihatsch $\mathrm{MJ}$, et al. A prospective study of renal structure and function in psoriasis patients treated with cyclosporin. Kidney Int. (1994) 46:1216-22. doi: $10.1038 /$ ki.1994.387

136. Li M, Maderdrut JL, Lertora JJL, Batuman V. Intravenous infusion of pituitary adenylate cyclase-activating polypeptide (PACAP) in a patient with multiple myeloma and myeloma kidney: a case study. Peptides. (2007) 28:1891-5. doi: 10.1016/j.peptides.2007.05.002

137. Rossing P, De Zeeuw D. Need for better diabetes treatment for improved renal outcome. Kidney Int. (2011) 79:528-32. doi: 10.1038/ki.20 10.513

138. Reglodi D, Atlasz T, Szabo E, Jungling A, Tamas A, Juhasz T, et al. PACAP deficiency as a model of aging. GeroScience. (2018) 40:437-52. doi: $10.1007 / \mathrm{s} 11357-018-0045-8$

139. Hauser-Kronberger C, Hacker GW, Albegger K, Muss WH, Sundler F, Arimura A, et al. Distribution of two VIP-related peptides, helospectin and pituitary adenylate cyclase activating peptide (PACAP), in 
the human upper respiratory system. Regul Pept. (1996) 65:203-9. doi: 10.1016/0167-0115(96)00100-0

140. Moody TW, Zia F, Makheja A. Pituitary adenylate cyclase activating polypeptide receptors are present on small cell lung cancer cells. Peptides. (1993) 14:241-6. doi: 10.1016/0196-9781(93)90036-G

141. Cardell LO, Uddman R, Luts A, Sundler F. Pituitary adenylate cyclase activating peptide (PACAP) in guinea-pig lung: distribution and dilatory effects. Regul Pept. (1991) 36:379-90. doi: 10.1016/0167-0115(91)90071-N

142. Wagner U, Bredenbröker D, Storm B, Tackenberg B, Fehmann HC, von Wichert P. Effects of VIP and related peptides on airway mucus secretion from isolated rat trachea. Peptides. (1998) 19:241-5. doi: 10.1016/S0196-9781(97)00257-X

143. Yoshihara S, Lindén A, Kashimoto K, Nagano Y, Ichimura T, Nadel JA. A novel PACAP 1-27 analogue causes sustained smooth muscle relaxation in guinea-pig trachea. Ann N Y Acad Sci. (1996) 805:536-42. doi: 10.1111/j.1749-6632.1996.tb17515.x

144. Yoshihara S, Yamada Y, Abe T, Kashimoto K, Lindén A, Arisaka O. Longlasting smooth-muscle relaxation by a novel PACAP analogue in human bronchi. Regul Pept. (2004) 123:161-5. doi: 10.1016/j.regpep.2004.04.023

145. Kinhult J, Adner M, Uddman R, Cardell LO. Pituitary adenylate cyclaseactivating polypeptide, effects in the human nose. Clin Exp Allergy. (2003) 33:942-9. doi: 10.1046/j.1365-2222.2003.01721.x

146. Lauenstein HD, Quarcoo D, Plappert L, Schleh C, Nassimi M, Pilzner C, et al. Pituitary adenylate cyclase-activating peptide receptor 1 mediates antiinflammatory effects in allergic airway inflammation in mice. Clin Exp Allergy. (2011) 41:592-601. doi: 10.1111/j.1365-2222.2010.03636.x

147. Moody TW, Nuche-Berenguer B, Jensen RT. Vasoactive intestinal peptide/pituitary adenylate cyclase activating polypeptide, and their receptors and cancer. Curr Opin Endocrinol Diabetes Obes. (2016) 23:38-47. doi: 10.1097/MED.0000000000000218

148. Zia F, Fagarasan M, Bitar K, Coy DH, Pisegna JR, Wank SA, et al. Pituitary adenylate cyclase activating peptide receptors regulate the growth of nonsmall cell lung cancer cells. Cancer Res. (1995) 55:4886-91.

149. Draoui M, Hida T, Jakowlew S, Birrer M, Zia F, Moody TW. PACAP stimulates c-fos mRNAs in small cell lung cancer cells. Life Sci. (1996) 59:307-13. doi: 10.1016/0024-3205(96)00299-8

150. Szanto Z, Sarszegi Z, Reglodi D, Nemeth J, Szabadfi K, Kiss P, et al. PACAP immunoreactivity in human malignant tumor samples and cardiac diseases. J Mol Neurosci. (2012) 48:667-73. doi: 10.1007/s12031-012-9815-4

151. Otto C, Hein L, Brede M, Jahns R, Engelhardt S, Gröne HJ, et al. Pulmonary hypertension and right heart failure in pituitary adenylate cyclase-activating polypeptide type i receptor-deficient mice. Circulation. (2004) 110:3245-51. doi: 10.1161/01.CIR.0000147235.53360.59

152. Mehta D, Granstein RD. Immunoregulatory effects of neuropeptides on endothelial cells: relevance to dermatological disorders. Dermatology. (2019) 235:175-86. doi: 10.1159/000496538

153. Steinhoff M, McGregor GP, Radleff-Schlimme A, Steinhoff A, Jarry $\mathrm{H}$, Schmidt WE. Identification of pituitary adenylate cyclase activating polypeptide (PACAP) and PACAP type 1 receptor in human skin: expression of PACAP-38 is increased in patients with psoriasis. Regul Pept. (1999) 80:49-55. doi: 10.1016/S0167-0115(99)00010-5

154. Warren JB, Larkin SW, Coughlan M, Kajekar R, Williams TJ. Pituitary adenylate cyclase activating polypeptide is a potent vasodilator and oedema potentiator in rabbit skin in vivo. Br J Pharmacol. (1992) 106:331-4. doi: 10.1111/j.1476-5381.1992.tb14336.x

155. Warren JB, Cockcroft JR, Larkin SW, Kajekar R, Macrae A, Ghatei $\mathrm{MA}$, et al. Pituitary adenylate cyclase activating polypeptide is a potent vasodilator in humans. J Cardiovasc Pharmacol. (1992) 20:83-7. doi: 10.1097/00005344-199220010-00011

156. Sasaki S, Watanabe J, Ohtaki H, Matsumoto M, Murai N, Nakamachi T, et al. Pituitary adenylate cyclase-activating polypeptide promotes eccrine gland sweat secretion. Br J Dermatol. (2017) 176:413-22. doi: 10.1111/bjd.14885

157. Choi JE, Di Nardo A. Skin neurogenic inflammation. Semin Immunopathol. (2018) 40:249-59. doi: 10.1007/s00281-018-0675-z

158. Atlasz T, Vaczy A, Werling D, Kiss P, Tamas A, Kovacs K, et al. Protective effects of PACAP in the Retina. In: Reglodi D, Tamas A, editors. Pituitary Adenylate Cyclase Activating Polypeptide - PACAP, Current Topics in Neurotoxicity 11. New York, NY: Springer Nature (2016). p. 501-27.
159. Atlasz T, Szabadfi K, Kiss P, Racz B, Gallyas F, Tamas A, et al. Pituitary adenylate cyclase activating polypeptide in the retina: focus on the retinoprotective effects. Ann N Y Acad Sci. (2010) 1200:128-39. doi: 10.1111/j.1749-6632.2010.05512.x

160. Yoshitomi T, Yamaji K, Ishikawa H, Ohnishi Y. Effect of pituitary adenylate cyclase-activating peptide on isolated rabbit iris sphincter and dilator muscles. Investig Ophthalmol Vis Sci. (2002) 43:7803.

161. Samuelsson-Almén M, Nilsson SF. Pituitary adenylate cyclase-activating polypeptide- and vip-induced activation of adenylate cyclase in the porcine non-pigmented ciliary epithelium: effects of antagonists. J Ocul Pharmacol Ther. (1999) 15:389-400. doi: 10.1089/jop.1999.15.389

162. Wang ZY, Alm P, Hakanson R. PACAP occurs in sensory nerve fibers and participates in ocular inflammation in the rabbit. Ann N Y Acad Sci. (1996) 805:779-83. doi: 10.1111/j.1749-6632.1996.tb17556.x

163. Werling D, Reglodi D, Banks WA, Salameh TS, Kovacs K, Kvarik T, et al. Ocular delivery of PACAP1-27 protects the retina from ischemic damage in rodents. Investig Ophthalmol Vis Sci. (2016) 57:6683-91. doi: $10.1167 /$ iovs.16-20630

164. Werling D, Banks WA, Salameh TS, Kvarik T, Kovacs L, Vaczy A, et al. Passage through the ocular barriers and beneficial effects in retinal ischemia of topical application of PACAP1-38 in rodents. Int J Mol Sci. (2017) 18:675. doi: 10.3390/ijms18030675

165. Xu HZ, Le YZ. Significance of outer blood-retina barrier breakdown in diabetes and ischemia. Invest Ophthalmol Vis Sci. (2011) 52:2160-4. doi: $10.1167 /$ iovs.10-6518

166. Willermain F, Janssens S, Arsenijevic T, Piens I, Bolaky N, Caspers L, et al. Osmotic stress decreases aquaporin-4 expression in the human retinal pigment epithelial cell line, ARPE-19. Int J Mol Med. (2014) 34:533-8. doi: $10.3892 / \mathrm{ijmm} .2014 .1791$

167. Veltmann M, Hollborn M, Reichenbach A, Wiedemann P, Kohen L, Bringmann A. Osmotic induction of angiogenic growth factor expression in human retinal pigment epithelial cells. PLoS ONE. (2016) 11:e0147312. doi: 10.1371/journal.pone.0147312

168. Adamis AP, Shima DT, Yeo KT, Yeo TK, Brown LF, Berse B, et al. Synthesis and secretion of vascular permeability factor/vascular endothelial growth factor by human retinal pigment epithelial cells. Biochem Biophys Res Commun. (1993) 193:631-8. doi: 10.1006/bbrc.1993.1671

169. Lopez PF, Sippy BD, Michael Lambert H, Thach AB, Hinton DR. Transdifferentiated retinal pigment epithelial cells are immunoreactive for vascular endothelial growth factor in surgically excised age-related macular degeneration-related choroidal neovascular membranes. Invest Ophthalmol Vis Sci. (1996) 37:855-68.

170. Simo R, Carrasco E, Garcia-Ramirez M, Hernandez C. Angiogenic and antiangiogenic factors in proliferative diabetic retinopathy. Curr Diabetes Rev. (2006) 2:71-98. doi: 10.2174/157339906775473671

171. Wirostko B, Wong TY, Simo R. Vascular endothelial growth factor and diabetic complications. Prog Retin Eye Res. (2008) 27:608-21. doi: 10.1016/j.preteyeres.2008.09.002

172. Witmer A, Vrensen GF, Van Noorden CJ, Schlingemann RO. Vascular endothelial growth factors and angiogenesis in eye disease. Prog Retin Eye Res. (2003) 22:1-29. doi: 10.1016/S1350-9462(02)00043-5

173. Pascolini D, Mariotti SP. Global estimates of visual impairment: 2010. Br J Ophthalmol. (2012) 96:614-8. doi: 10.1136/bjophthalmol-2011-300539

174. Zhang XY, Hayasaka S, Chi ZL, Cui HS, Hayasaka Y. Effect of pituitary adenylate cyclase-activating polypeptide (PACAP) on IL-6, IL-8, and MCP-1 expression in human retinal pigment epithelial cell line. Curr Eye Res. (2005) 30:1105-11. doi: 10.1080/02713680500421444

175. Wilhelm I, Krizbai IA. Effects of PACAP on biological barriers. In: Reglodi D, Tamas A, editors. Pituitary Adenylate Cyclase Activating Polypeptide PACAP, Current Topics in Neurotoxicity 11. New York, NY: Springer Nature (2016). p. 433-47.

176. Van C, Condro MC, Lov K, Zhu R, Ricaflanca PT, Ko HH, et al. PACAP/PAC1 regulation of inflammation via catecholaminergic neurons in a model of multiple sclerosis. J Mol Neurosci. (2019) 68:439-51. doi: 10.1007/s12031-018-1137-8

177. Abad C, Tan YV. Immunomodulatory roles of PACAP and VIP: lessons from knockout mice. J Mol Neurosci. (2018) 66:102-13. doi: 10.1007/s12031-018-1150-y 
178. Gonzalez-Rey E, Varela N, Chorny A, Delgado M. Therapeutical approaches of vasoactive intestinal peptide as a pleiotropic immunomodulator. Curr Pharm Des. (2007) 13:1113-39. doi: 10.2174/1381612077806 18966

179. Delgado M, Abad C, Martinez C, Juarranz MG, Leceta J, Ganea D, et al. PACAP in immunity and inflammation. Ann N Y Acad Sci. (2003) 992:14157. doi: 10.1111/j.1749-6632.2003.tb03145.x

180. Juhasz T, Helgadottir SL, Tamas A, Reglodi D, Zakany R. PACAP and VIP signaling in chondrogenesis and osteogenesis. Peptides. (2015) 66:51-7. doi: 10.1016/j.peptides.2015.02.001

181. Fulop BD, Sandor B, Szentleleky E, Karanyicz E, Reglodi D, Gaszner B, et al. Altered notch signaling in developing molar teeth of Pituitary Adenylate Cyclase-Activating Polypeptide (PACAP)-deficient mice. J Mol Neurosci. (2019) 68:377-88. doi: 10.1007/s12031-018-1146-7

182. Persson E, Lerner UH. The neuropeptide VIP regulates the expression of osteoclastogenic factors in osteoblasts. J Cell Biochem. (2011) 112:3732-41. doi: $10.1002 /$ jcb. 23304

183. Juhasz T, Matta C, Katona E, Somogyi C, Takacs R, Hajdu T, et al. Pituitary Adenylate Cyclase-Activating Polypeptide (PACAP) signalling enhances osteogenesis in UMR-106 cell line. J Mol Neurosci. (2014) 54:555-73. doi: 10.1007/s12031-014-0389-1

184. Jozsa G, Szegeczki V, Palfi A, Kiss T, Helyes Z, Fulop B, et al. Signalling alterations in bones of pituitary adenylate cyclase activating polypeptide (PACAP) gene deficient mice. Int J Mol Sci. (2018) 19:2538. doi: 10.3390/ijms19092538

185. Juhasz T, Szentleleky E, Somogyi CS, Takacs R, Dobrosi N, Engler M, et al. Pituitary adenylate cyclase activating polypeptide (PACAP) pathway is induced by mechanical load and reduces the activity of hedgehog signaling in chondrogenic micromass cell cultures. Int J Mol Sci. (2015) 16:17344-67. doi: 10.3390/ijms160817344

186. Sun ZP, Wu SP, Liang C De, Zhao CX, Sun BY. The synovial fluid neuropeptide PACAP may act as a protective factor during disease progression of primary knee osteoarthritis and is increased following hyaluronic acid injection. Innate Immun. (2019) 25:255-64. doi: 10.1177/1753425919839125

187. Sun BY, Sun ZP, Pang ZC, Huang WT, Wu SP. Decreased synovial fluid pituitary adenylate cyclase-activating polypeptide (PACAP) levels may reflect disease severity in post-traumatic knee osteoarthritis after anterior cruciate ligament injury. Peptides. (2019) 116:22-9. doi: 10.1016/j.peptides.2019.04.009

188. Grässel S, Muschter D. Do neuroendocrine peptides and their receptors qualify as novel therapeutic targets in osteoarthritis? Int J Mol Sci. (2018) 19:367. doi: 10.3390/ijms19020367

189. Vamos Z, Ivic I, Cseplo P, Toth G, Tamas A, Reglodi D, et al. Pituitary Adenylate Cyclase-Activating Polypeptide (PACAP) induces relaxations of peripheral and cerebral arteries, which are differentially impaired by aging. $J$ Mol Neurosci. (2014) 54:535-42. doi: 10.1007/s12031-014-0349-9

190. Ivic I, Fulop BD, Juhasz T, Reglodi D, Toth G, Hashimoto H, et al. Backup mechanisms maintain PACAP/VIP-induced arterial relaxations in pituitary adenylate cyclase-activating polypeptide-deficient mice. J Vasc Res. (2017) 54:180-92. doi: 10.1159/000457798

191. Edvinsson L, Tajti J, Szalardy L, Vecsei L. PACAP and its role in primary headaches. J Headache Pain. (2018) 19:21. doi: 10.1186/s10194-018-0852-4

192. Reglodi D, Vaczy A, Rubio-Beltran E, MaassenVanDenBrink A. Protective effects of PACAP in ischemia. J Headache Pain. (2018) 19:19. doi: 10.1186/s10194-018-0845-3

193. Ashina M, Martelletti P. Pituitary adenylate-cyclase-activating polypeptide (PACAP): another novel target for treatment of primary headaches? J Headache Pain. (2018) 19:33. doi: 10.1186/s10194-018-0860-4

194. Kortesi T, Tuka B, Nyari A, Vecsei L, Tajti J. The effect of orofacial complete Freund's adjuvant treatment on the expression of migraine-related molecules. J Headache Pain. (2019) 20:43. doi: 10.1186/s10194-019-0999-7

195. Banki E, Hajna Z, Kemeny A, Botz B, Nagy P, Bolcskei K, et al. The selective PAC1 receptor agonist maxadilan inhibits neurogenic vasodilation and edema formation in the mouse skin. Neuropharmacology. (2014) 85:538-47. doi: 10.1016/j.neuropharm.2014.06.019

196. Ivic I, Balasko M, Fulop BD, Hashimoto H, Toth G, Tamas A, et al. VPAC1 receptors play a dominant role in PACAP-induced vasorelaxation in female mice. PLoS ONE. (2019) 14:e0211433. doi: 10.1371/journal.pone. 0211433

197. Banki E, Sosnowska D, Tucsek Z, Gautam T, Toth P, Tarantini S, et al. Age-related decline of autocrine pituitary adenylate cyclase-activating polypeptide impairs angiogenic capacity of rat cerebromicrovascular endothelial cells. J Gerontol Ser A Biol Sci Med Sci. (2015) 70:665-74. doi: 10.1093/gerona/glu116

198. Sano H, Miyata A, Horio T, Nishikimi T, Matsuo H, Kangawa K. The effect of pituitary adenylate cyclase activating polypeptide on cultured rat cardiocytes as a cardioprotective factor. Regul Pept. (2002) 109:107-13. doi: 10.1016/S0167-0115(02)00193-3

199. Chang Y, Lawson LJ, Hancock JC, Hoover DB. Pituitary adenylate cyclase-activating polypeptide: localization and differential influence on isolated hearts from rats and guinea pigs. Regul Pept. (2005) 129:139-46. doi: 10.1016/j.regpep.2005.02.012

200. Hoover DB, Girard BM, Hoover JL, Parsons RL. PAC 1 receptors mediate positive chronotropic responses to PACAP-27 and VIP in isolated mouse atria. Eur J Pharmacol. (2013) 713:25-30. doi: 10.1016/j.ejphar.2013.04.037

201. Parsons RL, May V. PACAP-induced PAC1 receptor internalization and recruitment of endosomal signaling regulate cardiac neuron excitability. $J$ Mol Neurosci. (2019) 68:340-7. doi: 10.1007/s12031-018-1127-x

202. Alston EN, Parrish DC, Hasan W, Tharp K, Pahlmeyer L, Habecker BA. Cardiac ischemia-reperfusion regulates sympathetic neuropeptide expression through gp130-dependent and independent mechanisms. Neuropeptides. (2011) 45:33-42. doi: 10.1016/j.npep.2010.10.002

203. Sarszegi Z, Szabo D, Gaszner B, Konyi A, Reglodi D, Nemeth J, et al. Examination of Pituitary Adenylate Cyclase-Activating Polypeptide (PACAP) as a potential biomarker in heart failure patients. J Mol Neurosci. (2019) 68:368-76. doi: 10.1007/s12031-017-1025-7

204. Reglodi D, Tamas A, Koppan M, Szogyi D, Welke L. Role of PACAP in female fertility and reproduction at gonadal level - recent advances. Front Endocrinol (Lausanne). (2012) 3:155. doi: 10.3389/fendo.2012.00155

205. Brubel R, Boronkai A, Reglodi D, Racz B, Nemeth J, Kiss P, et al. Changes in the expression of pituitary adenylate cyclase-activating polypeptide in the human placenta during pregnancy and its effects on the survival of JAR choriocarcinoma Cells. J Mol Neurosci. (2010) 42:450-8. doi: 10.1007/s12031-010-9374-5

206. Lee J, Park HJ, Choi HS, Kwon HB, Arimura A, Lee BJ, et al. Gonadotropin stimulation of Pituitary Adenylate Cyclase-Activating Polypeptide (PACAP) messenger ribonucleic acid in the rat ovary and the role of PACAP as a follicle survival factor. Endocrinology. (1999) 140:818-26. doi: 10.1210/endo.140.2.6485

207. Koppan M, Varnagy A, Reglodi D, Brubel R, Nemeth J, Tamas A, et al. Correlation between oocyte number and follicular fluid concentration of Pituitary Adenylate Cyclase-Activating Polypeptide (PACAP) in women after superovulation treatment. J Mol Neurosci. (2012) 48:617-22. doi: 10.1007/s12031-012-9743-3

208. Nakamura K, Nakamachi T, Endo K, Ito K, Machida T, Oka T, et al. Distribution of pituitary adenylate cyclase-activating polypeptide (PACAP) in the human testis and in testicular germ cell tumors. Andrologia. (2014) 46:465-71. doi: 10.1111/and.12102

209. Tamas A, Javorhazy A, Reglodi D, Sarlos DP, Banyai D, Semjen D, et al. Examination of PACAP-like immunoreactivity in urogenital tumor samples. J Mol Neurosci. (2016) 59:177-83. doi: 10.1007/s12031-0150652-0

210. Meggyes M, Lajko A, Fulop BD, Reglodi D, Szereday L. Phenotypic characterization of testicular immune cells expressing immune checkpoint molecules in wild-type and pituitary adenylate cyclase-activating polypeptide-deficient mice. Am J Reprod Immunol. (2019) 22:e13212. doi: 10.1111/aji.13212

211. Lacombe A, Lelievre V, Roselli CE, Salameh W, Lue YH, Lawson G, et al. Delayed testicular aging in pituitary adenylate cyclase-activating peptide (PACAP) null mice. Proc Natl Acad Sci USA. (2006) 103:3793-8. doi: 10.1073/pnas.0505827103

212. Somoskoi B, Torok D, Reglodi D, Tamas A, Fulop BD, Cseh S. Possible effects of pituitary adenylate cyclase activating polypeptide (PACAP) on early embryo implantation marker HB-EGF in mouse. Reprod Biol. (2020) 20:9-13. doi: 10.1016/j.repbio.2020.01.005 
213. Lajko A, Meggyes M, Fulop BD, Gede N, Reglodi D, Szereday L. Comparative analysis of decidual and peripheral immune cells and immune-checkpoint molecules during pregnancy in wild-type and PACAP-deficient mice. Am J Reprod Immunol. (2018) 80:e13035. doi: 10.1111/aji.13035

214. Isaac ER, Sherwood NM. Pituitary adenylate cyclase-activating polypeptide (PACAP) is important for embryo implantation in mice. Mol Cell Endocrinol. (2008) 280:13-9. doi: 10.1016/j.mce.2007.09.003

215. Boronkai A, Brubel R, Racz B, Tamas A, Kiss P, Horvath G, et al. Effects of pituitary adenylate cyclase activating polypeptide on the survival and signal transduction pathways in human choriocarcinoma cells. Ann N Y Acad Sci. (2009) 1163:353-7. doi: 10.1111/j.1749-6632.2008.03630.x

216. Horvath G, Reglodi D, Brubel R, Halasz M, Barakonyi A, Tamas A, et al. Investigation of the possible functions of PACAP in human trophoblast cells. J Mol Neurosci. (2014) 54:320-30. doi: 10.1007/s12031-014-0337-0

217. Lee JH, Lee JY, Rho SB, Choi JS, Lee DG, An S, et al. PACAP inhibits tumor growth and interferes with clusterin in cervical carcinomas. FEBS Lett. (2014) 588:4730-9. doi: 10.1016/j.febslet.2014. 11.004

218. Oka H, Jin L, Kulig E, Scheithauer BW, Lloyd RV. Pituitary adenylate cyclaseactivating polypeptide inhibits transforming growth factor- $\beta 1$-induced apoptosis in a human pituitary adenoma cell line. Am J Pathol. (1999) 155:1893-900. doi: 10.1016/S0002-9440(10)65509-5

219. Gutiérrez-Cañas I, Rodríguez-Henche N, Bolaños O, Carmena MJ, Prieto JC, Juarranz MG. VIP and PACAP are autocrine factors that protect the androgen-independent prostate cancer cell line PC-3 from apoptosis induced by serum withdrawal. Br J Pharmacol. (2003) 139:1050-8. doi: 10.1038/sj.bjp.0705317

220. Horvath G, Reglodi D, Opper B, Brubel R, Tamas A, Kiss P, et al. Effects of PACAP on the oxidative stress-induced cell death in chicken pinealocytes is influenced by the phase of the circadian clock. Neurosci Lett. (2010) 484:148-52. doi: 10.1016/j.neulet.2010.08.039

221. Di Michele M, Peeters K, Loyen S, Thys C, Waelkens E, Overbergh L, et al. Pituitary Adenylate Cyclase-Activating Polypeptide (PACAP) impairs the regulation of apoptosis in megakaryocytes by activating NFКB: a proteomic study. Mol Cell Proteomics. (2012) 11:M111.007625. doi: 10.1074/mcp.M111.007625

222. Denes V, Geck P, Mester A, Gabriel R. Pituitary adenylate cyclase-activating polypeptide: 30 years in research spotlight and 600 million years in service. $J$ Clin Med. (2019) 8:1488. doi: 10.3390/jcm8091488

223. Aubert N, Vaudry D, Falluel-Morel A, Desfeux A, Fisch C, Ancian P, et al. PACAP prevents toxicity induced by cisplatin in rat and primate neurons but not in proliferating ovary cells: involvement of the mitochondrial apoptotic pathway. Neurobiol Dis. (2008) 32:66-80. doi: 10.1016/j.nbd.2008.06.014
224. Maugeri G, D’Amico AG, Reitano R, Magro G, Cavallaro S, Salomone $\mathrm{S}$, et al. PACAP and VIP inhibit the invasiveness of glioblastoma cells exposed to hypoxia through the regulation of HIFs and EGFR expression. Front Pharmacol. (2016) 7:139. doi: 10.3389/fphar.2016. 00139

225. Dufes C, Alleaume C, Montoni A, Olivier JC, Muller JM. Effects of the Vasoactive Intestinal Peptide (VIP) and related peptides on glioblastoma cell growth in vitro. J Mol Neurosci. (2003) 21:91-102. doi: 10.1385/JMN:21:2:91

226. Vertongen P, Camby I, Darro F, Kiss R, Robberecht P. VIP and pituitary adenylate cyclase activating polypeptide (PACAP) have an antiproliferative effect on the T98G human glioblastoma cell line through interaction with VIP2 receptor. Neuropeptides. (1996) 30:491-6. doi: 10.1016/S0143-4179(96)90015-3

227. Wojcieszak J, Zawilska JB. PACAP38 and PACAP6-38 exert cytotoxic activity against human retinoblastoma Y79 cells. J Mol Neurosci. (2014) 54:463-8. doi: 10.1007/s12031-014-0248-0

228. Cohen JR, Resnick DZ, Niewiadomski P, Dong H, Liau LM, Waschek JA. Pituitary adenylyl cyclase activating polypeptide inhibits glil gene expression and proliferation in primary medulloblastoma derived tumorsphere cultures. BMC Cancer. (2010) 10:676. doi: 10.1186/1471-240710-676

229. Li M, Cortez S, Nakamachi T, Batuman V, Arimura A. Pituitary adenylate cyclase-activating polypeptide is a potent inhibitor of the growth of light chain-secreting human multiple myeloma cells. Cancer Res. (2006) 66:87968803. doi: 10.1158/0008-5472.CAN-05-2809

230. Hayez N, Harfi I, Lema-Kisoka R, Svoboda M, Corazza F, Sariban E. The neuropeptides vasoactive intestinal peptide (VIP) and pituitary adenylate cyclase activating polypeptide (PACAP) modulate several biochemical pathways in human leukemic myeloid cells. J Neuroimmunol. (2004) 149:167-81. doi: 10.1016/j.jneuroim.2003.12.008

Conflict of Interest: The authors declare that the research was conducted in the absence of any commercial or financial relationships that could be construed as a potential conflict of interest.

Copyright (C) 2020 Toth, Szabo, Tamas, Juhasz, Horvath, Fabian, Opper, Szabo, Maugeri, D'Amico, D'Agata, Vicena and Reglodi. This is an open-access article distributed under the terms of the Creative Commons Attribution License (CC BY). The use, distribution or reproduction in other forums is permitted, provided the original author(s) and the copyright owner(s) are credited and that the original publication in this journal is cited, in accordance with accepted academic practice. No use, distribution or reproduction is permitted which does not comply with these terms. 